\title{
Phylogeny and classification of the Bucconidae (Aves, Galbuliformes) based on osteological characters
}

\author{
Sérgio Roberto Posso ${ }^{1}$; Reginaldo José Donatelli ${ }^{2}$, Vitor Q. Piacentini ${ }^{3}$ \& Anderson Guzzi ${ }^{4}$
}

1 Universidade Federal de Mato Grosso do Sul (UFMS). Três Lagoas, MS, Brasil. ORCID: http://orcid.org/0000-0002-7823-9068. E-mail: srposso@hotmail.com

${ }^{2}$ Universidade Estadual Paulista "Júlio de Mesquita Filho" (UNESP). Bauru, SP, Brasil. ORCID: http://orcid.org/0000-0002-5988-2226. E-mail: rjdonat@yahoo.com.br

${ }^{3}$ Universidade Federal de Mato Grosso (UFMT). Cuiabá, MT, Brasil. ORCID: http://orcid.org/0000-0003-1571-2222. E-mail: vitor.piacentini@gmail.com

${ }^{4}$ Universidade Federal do Piauí (UFPI). Parnaíba, PI, Brasil. ORCID: http://orcid.org/0000-0001-7206-7683. E-mail: guzzi@ufpi.edu.br

\begin{abstract}
The puffbirds (Bucconidae) are relatively poorly studied birds whose intrafamilial relationships have not yet been explored within a phylogenetic framework in a published study. Here, we performed a parsimony analysis of osteological data obtained following the examination of all the genera and 32 out of the 36 species recognized in Bucconidae currently. The analysis yielded eight equally parsimonious trees (426 minimum steps). Ambiguous relationships were observed only in Notharcus ordii, Malacoptila fusca, and Nonnula rubecula. Notably, Bucco was polyphyletic, leading to the resurrection of Cyphos and Tamatia. In addition, the osteological data provided a well-resolved phylogeny (topological dichotomies) and the support indices indicated that most of the nodes were robust at all hierarchical levels. We thus propose the first revised classification of the Bucconidae.
\end{abstract}

Key-Words. Puffbirds; Morphology; Systematics.

\section{INTRODUCTION}

The Bucconidae (puffbirds) comprises 10 genera and 36 species (Remsen et al., 2020) endemic to the Neotropics, with the highest diversity in the Amazon Basin. They are mostly silent and secretive birds, perching motionless for long periods (Rasmussen \& Collar, 2002), which makes it challenging to study them in the Neotropical forests. Therefore, the behavior, breeding, morphology, and systematics of these arboreal, colorful, and insectivorous birds are poorly understood.

Some studies have been conducted on puffbirds, Steinbacher (1937) published the first anatomical description of some species of the Bucconidae, while Höfling \& Alvarenga (2001) compared the shoulder girdle of this family with those of other birds, and Ladeira \& Höfling (2007) described the cranial osteology of seven genera in the Bucconidae. However, both of the latter studies did not entail systematics analyses. The first analysis of phylogenetic interrelationships among the Bucconidae was performed by Witt (2004) to estimate the mitochondrial DNA evolution rates for application in Neotropical avian biogeography studies, while Duarte (2015) performed a phylogenetic analysis including Nystalus based on molecular datasets. However, the findings of both studies remain unpublished. Ferreira, Aleixo, Ribas \& Santos (2016) performed a phylogenetic analysis to infer biogeography patterns of puffbirds in South America; however, they restricted themselves to the genus Malacoptila. In addition, no studies on within-family relationships based on modern analytical methods have been published (Remsen et al., 2020).

Consequently, this study presents: a) a phylogenetic hypothesis for the Bucconidae based on osteological data and b) a formal classification that reflects relationships inferred from the hypothesis, for the first time, in these Neotropical birds.

\section{MATERIAL AND METHODS}

The present study compared 200 complete skeletons belonging to 44 species. We studied 123 main skeletons belonging to 32 Bucconidae species. The study encompasses almost all the Bucconidae species, excluding Bucco noanamae Hellmayr, 1909; Nonnula amaurocephala Chapman, 1921 and Notharcus pectoralis (Gray, 1846). Further, our sample of the Nystalus striolatus complex (from Peru and Bolivia) actually refers to the recently splitted Nystalus obamai Whitney, Piacentini, Schunck, Aleixo, Sousa, Silveira \& Rêgo, 
2013. Galbulidae was selected as the out-group based on 77 specimens from 7 genera and 12 species. All specimens had been prepared previously (dried structures) and belong to collections in Brazil and USA (Table 1).

The comparative osteology examinations were carried out under stereomicroscopes $(9.6 \times-60 \times)$. Some bone structures (characters 2, 6, 11, 15, 38, 40, 45, 59, 74, 75, 80, 89, 92, 100, 101, 103, 105, 109, 112, 115, 120, 123, 131, and 133, Appendix 1) were measured with a Mitutoyo digital caliper with a $0.01-\mathrm{mm}$ accuracy. We adopted the averages of three measurements and the relative sizes (percentages) of each structure were compared with the relative sizes of other structures to avoid misunderstandings about different body sizes within the Bucconidae/ Galbulidae species (Figs. 1-5).

The anatomical nomenclature was according to the proposal in Nomina Anatomica Avium (Baumel \& Witmer, 1993) and was supplemented by recent suggestions by Posso \& Donatelli (2005).

Characters for which information was unavailable were coded as missing (?) and multistate characters that were considered binary characters were treated

Table 1. List of the specimens (alphabetical order). FMNH = Field Museum of Natural History; LSU, USA = Lousiania States University, USA; MZUSP = Museu de Zoologia Universidade de São Paulo, Brazil; USNM = United States National Museum, USA; MPEG = Museu Paraense Emilio Goeldi, Brazil.

\begin{tabular}{|c|c|}
\hline Species & Museum and number of collection \\
\hline \multicolumn{2}{|l|}{ Bucconidae } \\
\hline Bucco capensis Linnaeus, 1766 & LSU 111183, 118362, 118363; MZUSP 87231, USNM 621739, FMNH 330305, 318888. \\
\hline Chelidoptera tenebrosa (Pallas, 1782) & LSU 111187, 101291, 101290; MPEG 1029, 1030. \\
\hline Cyphos macrodactylus (Spix, 1824) & LSU 93946, 74869, 62751, 65001; FMNH 321004, 321000, 315414, 321005. \\
\hline Hapaloptila castanea (Verreaux, 1866) & LSU 1815,92014 \\
\hline Hypnelus ruficollis (Wagler, 1829) & FMNH 339641, 372629. \\
\hline Malacoptila fulvogularis Sclater, 1854 & LSU 107094, 95365; FMNH 291778, 291779, 321035, 321036. \\
\hline M. fusca (Gmelin, 1788) & LSU 111184, 111185, 107093, 107092, 165799. \\
\hline M. mystacalis (Lafresnaye, 1850) & FMNH 376707. \\
\hline M. panamensis Lafresnaye, 1847 & LSU 108757, 108758, 108759. \\
\hline M. rufa (Spix, 1824) & MZUSP 88209; LSU 118364, 118367, 118365, 118366, 553364, 562213; MPEG 2707, 2708. \\
\hline M. semicincta Todd, 1925 & LSU 52694, 70217, 131478; MZUSP 89415. \\
\hline M. striata (Spix, 1824) & MZUSP 89408, 89409, 89410, 89411, 89412, 89413, 89414. \\
\hline Micromonacha lanceolata (Deville, 1849) & LSU $118368,171211$. \\
\hline Monasa atra (Boddaert, 1783) & MZUSP 87231; LSU 68991; FMNH 317350, 317351, 317352. \\
\hline M. flavirostris Strickland, 1850 & LSU 111186, 121041. \\
\hline M. morphoeus (Hahn \& Küster, 1823) & MZUSP 88279; LSU 48581, 62749, 62750, 93947, 101289, 153957; FMNH 290502. \\
\hline M. nigrifrons (Spix, 1824) & LSU 73066, 118568, 70218, 13215, 48775, 52695, 125757, 136722; MZUSP 88139, MPEG 94. \\
\hline Nonnula brunnea Sclater, 1881 & LSU 48776. \\
\hline N. frontalis (Sclater, 1854) & LSU 108760, 108761, 108762, 108763. \\
\hline N. ruficapilla (Tschudi, 1844) & LSU 99592; FMNH 290247. \\
\hline N. rubecula (Spix, 1824) & LSU 118369; MZUSP 87232. \\
\hline N. sclateri Hellmayr, 1907 & LSU 50771. \\
\hline Notharcus hyperhynchus (Sclater, 1856) & FMNH 330301; USNM 500432; LSU 108748. \\
\hline N. macrorhynchus (Gmelin, 1788) & LSU 93945; USNM 623128. \\
\hline N. ordii (Cassin, 1851) & FMNH 318882. \\
\hline N. swainsoni (Gray, 1846) & MZUSP 89416. \\
\hline N. tectus (Boddaert, 1783) & LSU 136721, 165798; USNM 610217. \\
\hline Nystalus chacuru (Vieillot, 1816) & LSU 125759, 151641; MZUSP 89417, 89418, 89419, 89420; MPEG 19, 252. \\
\hline N. maculatus (Gmelin, 1788) & FMNH 334413; LSU 153898, 125758. \\
\hline N. radiatus (Sclater, 1854) & LSU 108756. \\
\hline N. striolatus (Pelzeln, 1856) or N. obamai Whitney et al., 2013 & LSU 131477; FMNH 291777. \\
\hline Tamatia tamatia (Gmelin, 1788) & USNM 622256; LSU 151640; FMNH 05547. \\
\hline \multicolumn{2}{|l|}{ Galbulidae } \\
\hline Brachygalba lugubris (Swainson, 1838) & LSU 136720; USNM 345911, 345912, 559511, 622889, 637212, 428703; FMNH 317347, 330287. \\
\hline B. salmoni (Spix, 1824) & LSU 108755; USNM 430945, 432631. \\
\hline Caucalias leucogastra (Vieillot, 1817) & LSU 93944; USNM 345910; FMNH 330295. \\
\hline Galbalcyrhynchus leucotis Des Murs, 1845 & LSU $118567,118353$. \\
\hline G. purusianus Goeldi, 1904 & LSU 48773. \\
\hline Galbina ruficauda (Cuvier, 1816) & $\begin{array}{l}\text { LSU 31900, 101288; USNM 555700, 612055, 612056, 612057, 15989, 322980, 289820, 344108, 344109, 345907, 345909, 612066, } \\
\text { 345908; FMNH 313424, 313425, 330293, 334410, 335024, } 337030 .\end{array}$ \\
\hline Galbula albirostris Latham, 1790 & LSU 50918, 111180, 118355, 118356; USNM 621409, 621976; FMNH 317348, 317349, 318877, 318878, 343795. \\
\hline G. cianicolis Cassi, 1851 & USNM 492312, 492329; FMNH 330290. \\
\hline G. cyanescens Deville, 1849 & LSU 107091, 48774; FMNH 289330, 289331, 289332, 320995, 320996, 320997, 320998, 320999, 433242. \\
\hline G. galbula Linnaeus, 1766 & USNM 500436. \\
\hline Jacamerops aureus (Muller, 1776) & LSU 87600, 118361; USNM 429779, 430890, 492873, 637205, 430943; FMNH 397899. \\
\hline Urogalba dea (Linnaeus, 1758) & LSU 131476, 165796; USNM 492280, FMNH 330299, 376705, 376706. \\
\hline
\end{tabular}


as not comparable (-) to avoid character duplication. Equal weights were assigned to the characters and all multistate characters were treated as unordered (Appendices 1 and 2).

The phylogenetic relationships were obtained using TNT software (Goloboff et al., 2008). Heuristic searches algorithm was selected to identify the best scored trees, and MAXTREES was set at 1000 trees. Random additive sequence analysis and tree-bisection-reconnection branch swapping algorithms were also adopted, saving 10 trees per replicate (MulTrees). Bootstrap (500 pseudoreplicates) and ratchet-minimized support (Bremer) indices were calculated to assess the nodes support.

The species nomenclature and classification were according to Remsen et al. (2020). Changes in nomencla- ture are proposed in line with the International Code of Zoological Nomenclature (ICZN, 1999).

\section{RESULTS AND DISCUSSION}

Different states from 135 characters (87 cranial and 48 postcranial) were selected (Appendix 1) and distributed among 33 taxa to reconstruct puffbird phylogeny. The matrix is available in Appendix 2.

The synapomorphies uniting the major clades are mentioned below and also they are shown in the Figs. 1 to 5 . However, the synapomorphies among the species in each genus, the number of steps, consistency indices, and polarizations of each character are presented in Appendix 3.
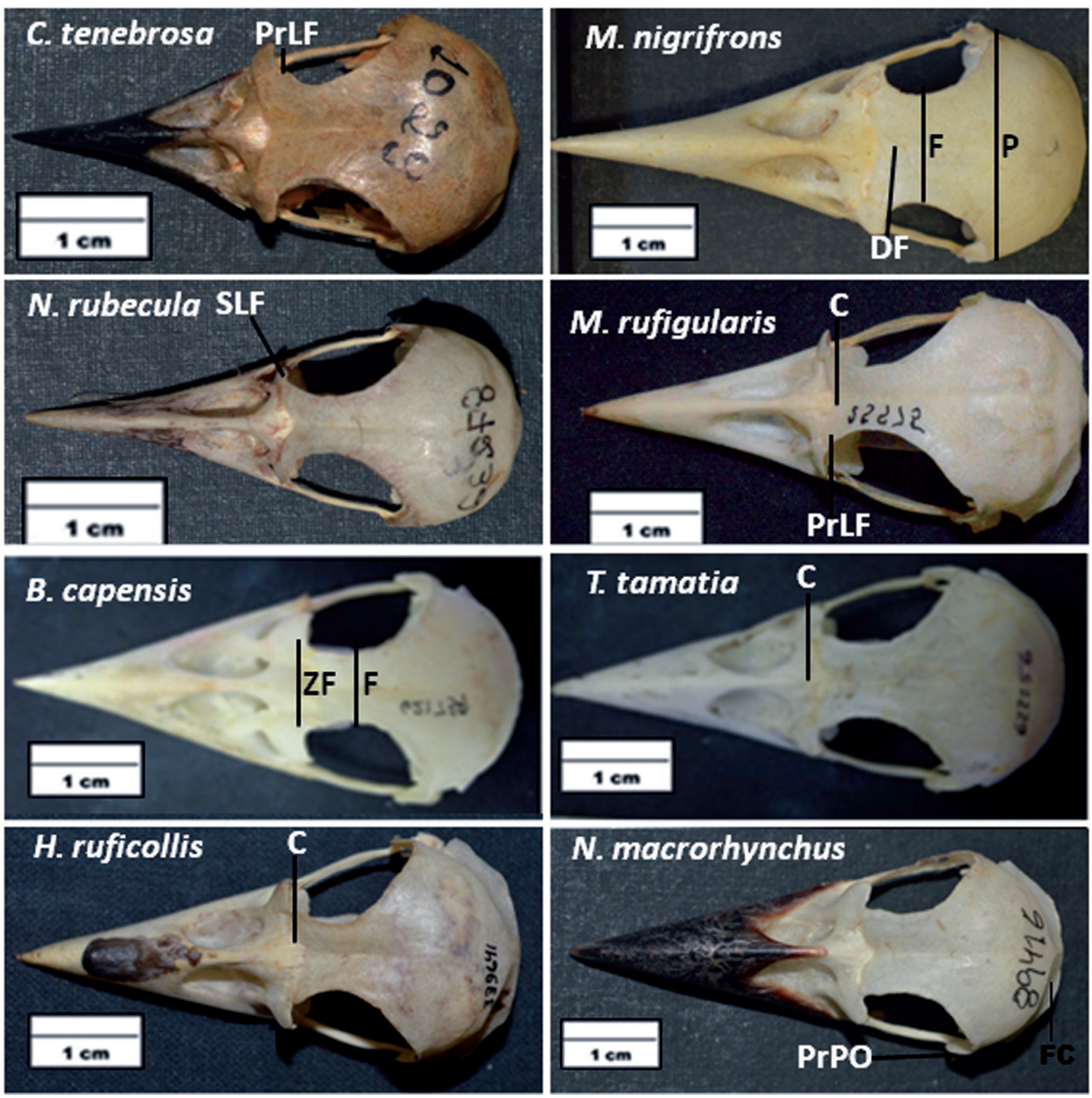

Figure 1. Dorsal view of the skull. $\mathrm{C}=$ concavity in the fissura zona flexoria craniofacialis; $\mathrm{DF}=$ depressio frontalis; $\mathrm{F}=$ os frontale; $\mathrm{FC}=$ fossa caudalis; $\mathrm{P}=$ os parietale; $\mathrm{PrFL}=$ proc. lacrimalis os frontale; $\mathrm{PrPO}=$ proc. postorbitalis; $\mathrm{SFL}=$ suture between os frontale and os lacrimalis; $\mathrm{ZF}=$ zona flexoria craniofacialis. 
The analysis recovered eight equally parsimonious trees, each with 426 steps. Fig. 6 presents the strict consensus tree. The analysis revealed that most of the genus within Bucconidae recognized currently is valid, with numerous apomorphies observed on the basal stem of each clade.

According to Rasmussen \& Collar (2002), Galbulidae and Bucconidae are similar in terms of behavior, external morphology, and anatomy, excluding the shape of the spinal cord and the number of ribs. Höfling \& Alvarenga
(2001) also observed five exclusive similarities between them on the shoulder girdle. However, the present study revealed major osteological differences between the two families: 56 from the skull/mandible and 24 from the post-cranial skeleton. Although they are considered to belong to the same order, the osteological modifications suggest they diverged from one another early. The present study also reveals polymorphism in os lacrimalis, fossa temporalis, and os palatinum within the Bucconidae, as
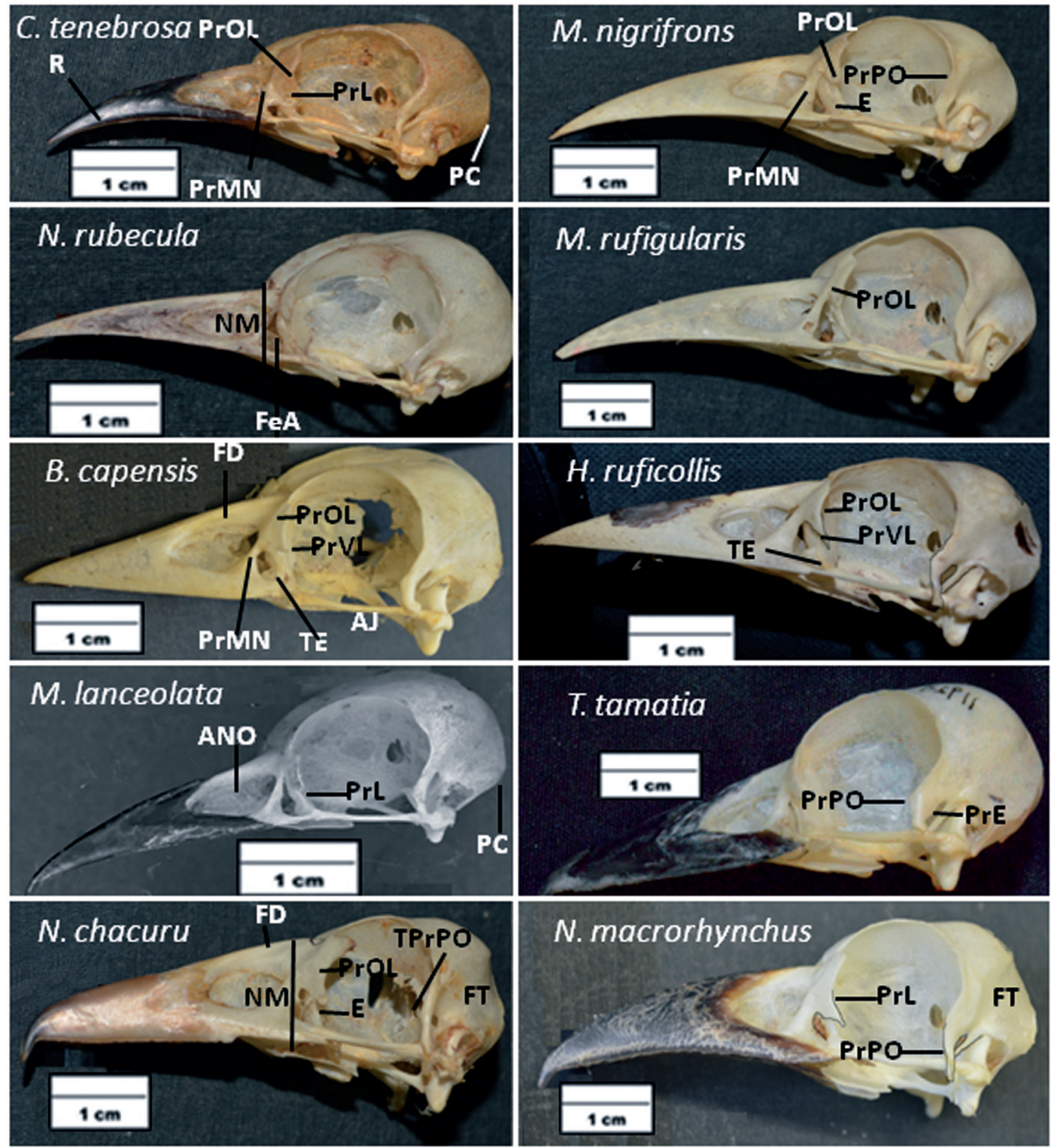

Figure 2. Lateral view of the skull. $\mathrm{AJ}=$ arcus jugalis; $\mathrm{ANO}=$ apertura nasi ossea; $\mathrm{CrD}=$ crista dorsalis os pterigoideus; $\mathrm{CrV}=$ crista ventralis os palatinum; $\mathrm{E}=$ os ectethmoidale; $\mathrm{FD}=$ facies dorsalis of the maxilla (upper jaw); $\mathrm{FeA}=$ fenestra anteorbitalis; $\mathrm{FT}=$ fossa temporalis; $\mathrm{NM}=$ nasal $/$ maxillary heigth; $\mathrm{PC}=$ proeminentia cerebelaris; $\mathrm{PRE}=$ proc. esquamosalis; $\mathrm{PrL}=$ proc. lacrimalis; $\mathrm{PrMN}=$ proc. maxillaris os nasale; $\mathrm{PrOL}=$ proc. orbitalis os lacrimale; $\mathrm{PrPO}=$ proc. postorbitalis; $\mathrm{PrTP}=$ proc. transplatinum os palatinum; $\mathrm{PrVL}=$ proc. ventralis os lacrimale; $\mathrm{TE}=$ tuberculum os ectethmoidale; $\mathrm{TPrPO}=$ tuberculum of the proc. postorbitalis. 
described in Ladeira \& Höfling (2007). However, the proc. postorbitalis, os ectethmoidale, os quadratum, the upper and lower jaws, the relative sizes of tibiotarsus/tarsometatarsus/femur and the second/forth toes and numerous features of the shoulder girdle and pelvis are also highly variable and, therefore, would facilitate the establishment of primary homologies.

Most of the primary homologies established in Ladeira \& Höfling (2007), which were listed in support of Monasal Malacoptila/Nonnula/Chelidoptera, were recovered as symplesiomorphies in our analysis. This is particularly notable in the case of Chelidoptera tenebrosa (Pallas, 1782) as it emerges as an isolated lineage from (sister-group of) the other Bucconidae. Chelidoptera tenebrosa exhibits major osteological variations in comparison with the other Bucconidae species, particularly in the skull structures. Consequently, the apomorphies that support the $C$. ten- ebrosa clade (Chelidopterinae) are as follows: the proc. lacrimalis os frontale is laterally large (Fig. 1, character 3, series of transformation 0-2); the proeminentia cerebelaris is tubercular and laterally large (Figs. 2 and 3, 12, 1-2); proc. lacrimalis is thick with medial curvature and large with lateral concavity (Fig. 2, 24, 1-3); the proc. orbitalis os lacrimale is lateromedially large with medial curvature (Figs. 2 and 3, 2, 28, 1-2); the proc. maxillaris os nasale is narrow (bar-shaped) and laterally large (Fig. 2, 42, 1-3); the fossa ventralis os palatinum is deep, long and large (Fig. 3, $58,2-4)$; the caudal portion os palatinum is larger than the rostral portion (Fig. 3, 59, 0-2); the fossa caudalis mandible is narrow and shallow (Fig. 4, 87, 1-2); the proc. dorsalis terminalis ischii broads $5 \%$ of the synsacrum (Fig. 5, 102, 0-1) and the apex of the ramphotheca has a long curvature (Fig. 2, 134, 1-2). Puffbirds are forest and sit-and-wait hunters; however, $C$. tenebrosa lives in more open coun-
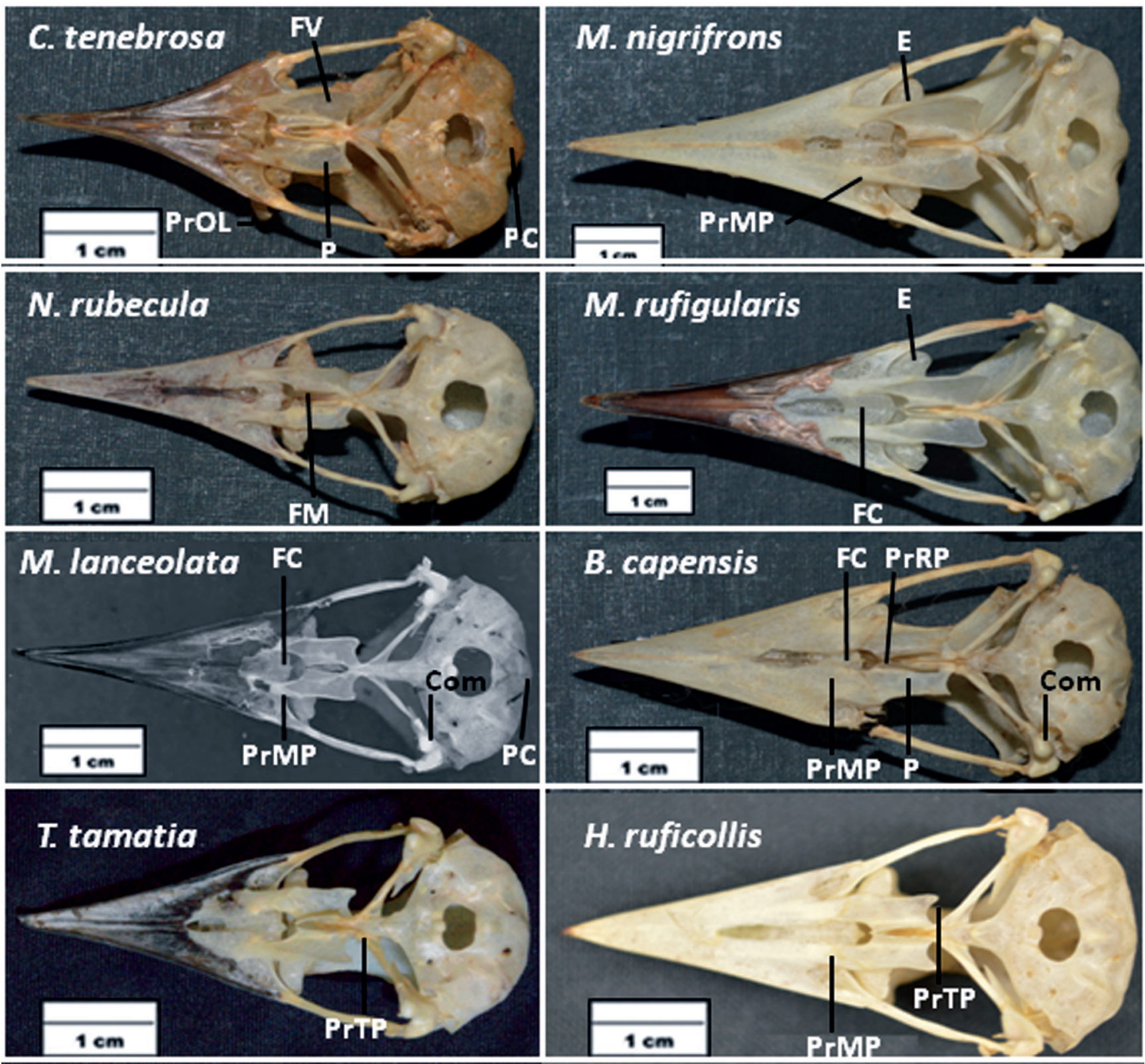

Figure 3. Ventral view of the skull. $\mathrm{Com}=$ condylus medialis os quadratum is longer and larger; $\mathrm{E}=$ os ectethmoidale; $F \mathrm{FC}=$ fossa choanalis; $F \mathrm{FM}=$ fossa medialis; $F \mathrm{FV}=$ fossa ventralis; $\mathrm{P}=$ os palatinum; $\mathrm{PC}=$ proeminentia cerebelaris; $\mathrm{PrOL}=$ proc. orbitalis os lacrimale; $\mathrm{PrMP}=$ proc. maxillaris os palatinum; $\mathrm{PrPP}=$ proc. pterigoideus os palatinum; $\mathrm{PrRP}=$ proc. rostrodorsalis os palatinum; $\operatorname{PrTP}=$ proc. transpalatinus os palatinum; $\operatorname{PrVL}=$ proc. ventralis os lacrimale. 
try and captures insects from open perches, in addition to exhibiting distinctive external morphology, particularly a dark plumage and a short beak, and it is a unique swallow-winged puffbird (Sick, 1997; Rasmussen \& Collar, 2002). For the reasons above, we placed C. tenebrosa in a monotypic and new sub-family, Chelidopterinae, as opposed to a nominate subfamily, Bucconinae.

The synapomorphies of the sub-family Bucconinae are as follows: the proc. postorbitalis is large and long, close to arcus jugalis (Fig. 2, 15, 0-1); the tuberculum in the rostroventral portion of the proc. postorbitalis is short (Fig. 2, 16, 0-1); the ventral portion of the proc. orbitalis os lacrimale is long, narrow, but sharp in its extremity (Fig. 2, 31, 0-2); the os ectethmoidale is thick (Figs. 2 and 3, $32,0-1)$; the foramem orbitonasalis lateralis is large $(36,0-1)$; the proc. transpalatinus os palatinum is long (Fig. 3, 56, 0-1); the fonticuli lateralis of ala preacetabularis is short $(91,1-2)$; the caudal tuberculum in the lateral surface of ala preacetabularis is prominent (Fig. 5, 96, 0-1); the tuberculum on the dorsal surface sulcus articularis with os coracoideum is vestigial (Fig. 5, 104, 0-1); the proc. craniolateralis is long ( $20 \%$ of the total length os sternum) (Fig. 5, 109, 0-1); the sulcus intercnemialis is narrow and shallow (Fig. 5, 130, 0-1); the facies gastrocnemialis os tibiotarsus is large and deep (Fig. 5, 132, 0-1) and the total length os tarsometatarsus reaches $90 \%$ the total length os femoris (Fig. 5, 133, 0-1).

Within the Bucconinae, Monasa Vieillot, 1816, is the sister-group to the remaining species with robust node support and the highest number of synapomorphies (see above). The findings justified maintaining Monasa in the same subfamily as the other Bucconinae. Monasa is monophyletic, supported by six synapomorphies with high support indices. The clade of the genus is supported by the depression frontalis shallow (Fig. 1, 1, 2-1); the os frontale reaches $50 \%$ of the os parietale (Fig. 1, 2, 1-0); the os ectethmoidale is short, sharp and long (Figs. 2 and 3, 33, 2-1); the tuberculum os ectethmoidale is prominent (Fig. 2, 35, 1-2); proc. maxillaris os nasale is bar-shaped (Fig. 2, 42, 1-2) and the os tibiotarsus is $40 \%$ longer than the os femoris (Fig. 5, 131, 1-0). Its monophyly has never been questioned. The Monasa species are quite similar to each other based on their plumage and they are the most vocal puffbird species, with a large repertoire of calls and songs, and they often give very loud shouts (Rasmussen \& Collar, 2002). In addition, they
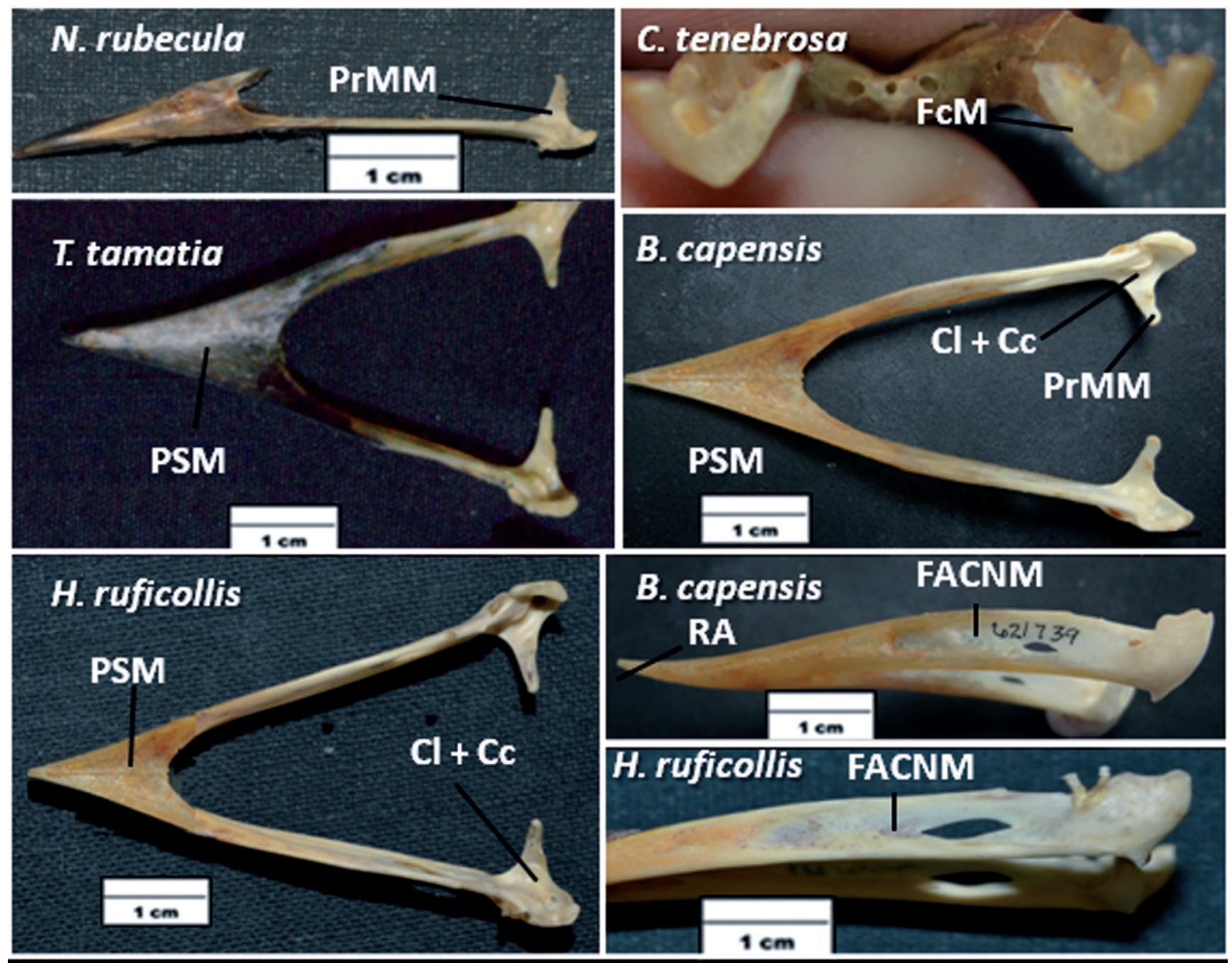

Figure 4. Mandible: Dorsal view of N. rubecula, T. tamatia, B. capensis and H. ruficollis; caudal view of C. tenebrosa and lateral view of $B$. capensis and $H$. ruficollis. $\mathrm{Cl}+\mathrm{C} C=$ cotyla lateralis and cotyla caudalis; $\mathrm{FACNM}=$ fossa aditus canalis neurovascularis mandible; $\mathrm{FcM}=$ fossa caudalis mandibulae; $\operatorname{PrMM}=$ Proc. medialis mandibulae; $\mathrm{PSM}=$ Pars simphisialis mandibulae; $\mathrm{RA}=$ rostral apex of the mandible. 
are more gregarious and are found in flocks (Sick, 1997). In our view, the characteristics justify the placement of Monasa within a new tribe of its own, Monasini, within the Bucconinae. The internal arrangement of the Monasa species based on the osteological analysis is dichotomous: (Monasa atra [Boddaert, 1783]/Monasa morphoeus [Hahn \& Küster, 1823]) and (Monasa flavirostris Strickland, 1850/Monasa nigrifrons [Spix, 1824]). Monasa flavirostris and $M$. nigrifrons were grouped together based on five synapomorphies and had higher support indices; however, the M. atra/M. morphoeus branch had low support indices, and it was supported by four synapomorphies.
Monasa flavirostris has plumage that is similar with that of M. atra, and it is thought to be related closely to M. atra and M. morphoeus (Rasmussen \& Collar, 2002). Although the similarities seem plesiomorphic, further systematics analyses should be carried out within Monasa based on other characters as sources of data.

The following node (3, Fig. 6) places Nonnula Sclater, 1854 as a sister-group of the other Bucconinae, excluding Monasa, with high support indices and eight synapomorphies: the suture between os frontale and os lacrimalis is short (Fig. 1, 23, 0-1); the fenestra anteorbitalis is triangular (Fig. 2, 37, 0-1); the caudal portion of the
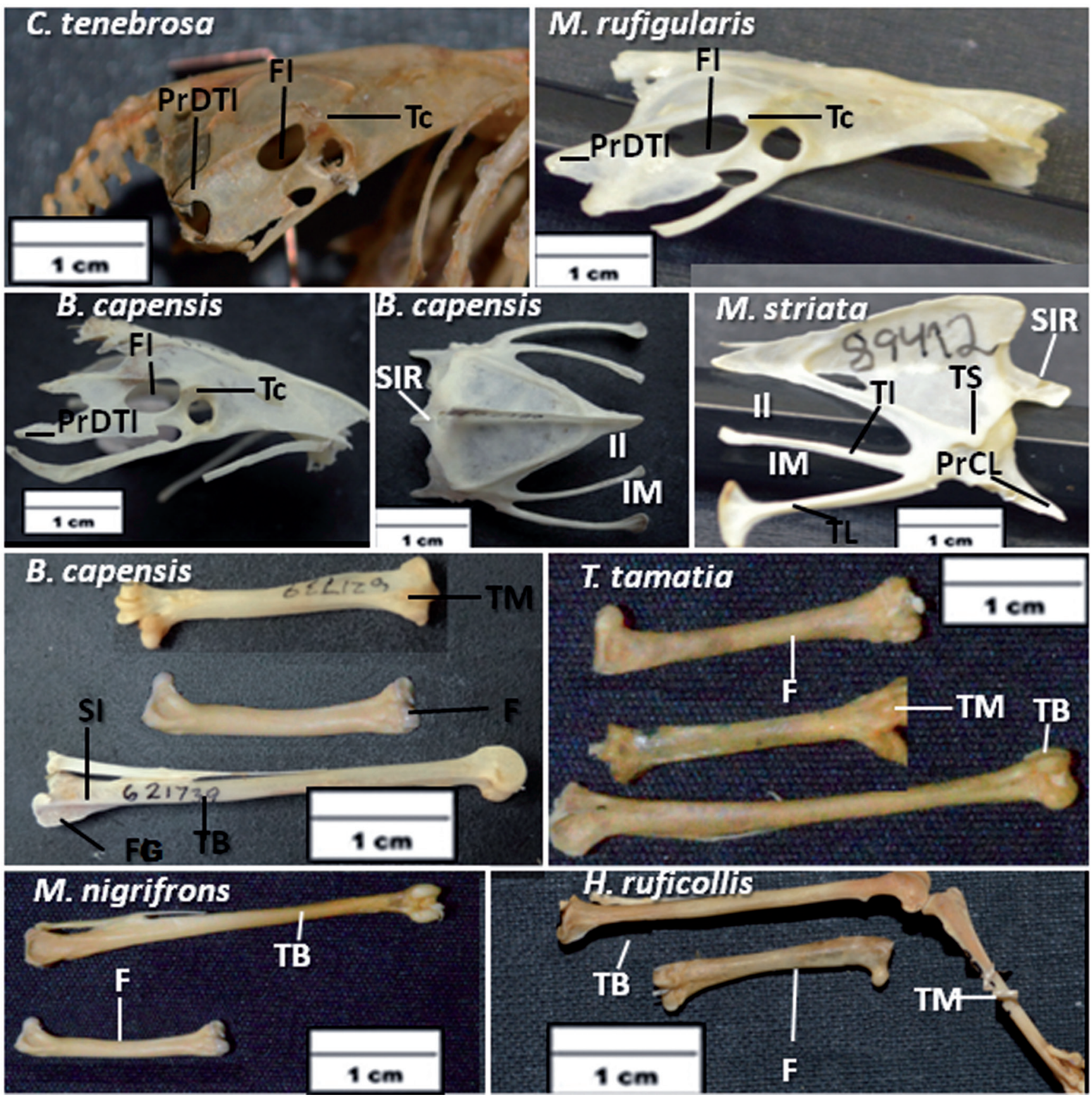

Figure 5. Lateral view of the pelvic region of C. tenebrosa, M. rufigularis and B. capensis; dorsal view of the os sternum of B. capensis and lateral view of the os sternum of M. striata; lateral view of os tibiotarsus, tarsometatarsus and os femoris of $B$. capensis, T. tamatia, M. nigrifrons and $H$. ruficollis. $F=0$ s femoris; $F G=$ facies gastrocnemialis os tibiotarsus; $\mathrm{FI}=$ foramen ilioschiadicum; $\mathrm{IL}=$ Incisura lateralis or fenestra lateralis; $\mathrm{IM}=$ incisura medialis or fenestra medialis; $\operatorname{PrCL}=$ proc. craniolateralis; $\mathrm{PrDTI}=$ proc. dorsalis terminalis ischii; $\mathrm{SI}=$ suclus intercnemialis; $\mathrm{SIR}=$ spina interna rostri; $\mathrm{TB}=$ os tibiotarsus; $\mathrm{Tc}=$ caudal tuberculum in the lateral surface of ala preacetabularis; $\mathrm{Tl}=$ trabecula intermedia; $\mathrm{TL}=$ trabecula lateralis; $\mathrm{TM}=$ os tarsometatarsus; $\mathrm{TS}=$ tuberculum sulcus articularis. 
upper jaw (os nasale and os maxillare) (NM) is dorsally large (about $70 \%$ of the narrow caudoventral portion of the upper jaw) (Fig. 2, 40, 2-1); the fossa medialis os palatinum is large (Fig. 3, 53, 0-1); the foramen ilioschiadicum is $50 \%$ of the total length of the synsacrum (Fig. 5, 92, 2-0); the trabecula intermedia of the os sternum is $60 \%$ of the total length os sternum (Fig. 5, 112, 1-0); the tuberculum on the dorsal surface os metacarpale is prominent (Fig. 5, 126, 2-1); $4^{\text {th }}$ toes is longer than $2^{\text {th }}$ toes (ossa digitorum pedis) $(135,0-1)$. The node grouping all Nonnula species is robust and supported by 12 synapomorphies: the os frontale reaches $20 \%$ of the os parietale (Fig. 1, 2, 1-2); the proc. suprameaticus is long (Fig. 2, 11, 0-1); the proeminentia cerebelaris is tubercular and laterally large (12, 1-2); the proc. postorbitalis is short (reduced)
$(15,1-0)$; the proc. orbitalis os lacrimale is reduced and triangular-shaped $(28,1-3)$; the proc. transpalatinus is long and sharp (Fig. 3, 56, 1-2); the tuberculum of the proc. opticus os quadratum is absent $(72,1-0)$; the proc. medialis mandible is short ( $8 \%$ mandible) (Fig. 4, 80, 2-1); the fossa caudalis mandible is narrow and shallow (Fig. 4, $87,1-2)$; the caudal tuberculum of the ala preacetabularis is prominent and large (Fig. 5, 96, 1-2); the trabecula lateralis os sternum reaches $70 \%$ of the os sternum (Fig. 5 , $111,0-1)$ and the os tarsometatarsus is longer than the os femoris (Fig. 5, 133, 1-2). Therefore, the osteological data and the small body size $(12-14 \mathrm{~cm})$ support the recognition of Nonnula. In addition, the plumage has a reddish-brown pattern on the underparts and the wings and tails (underparts) are dark-brown, and they are usu-

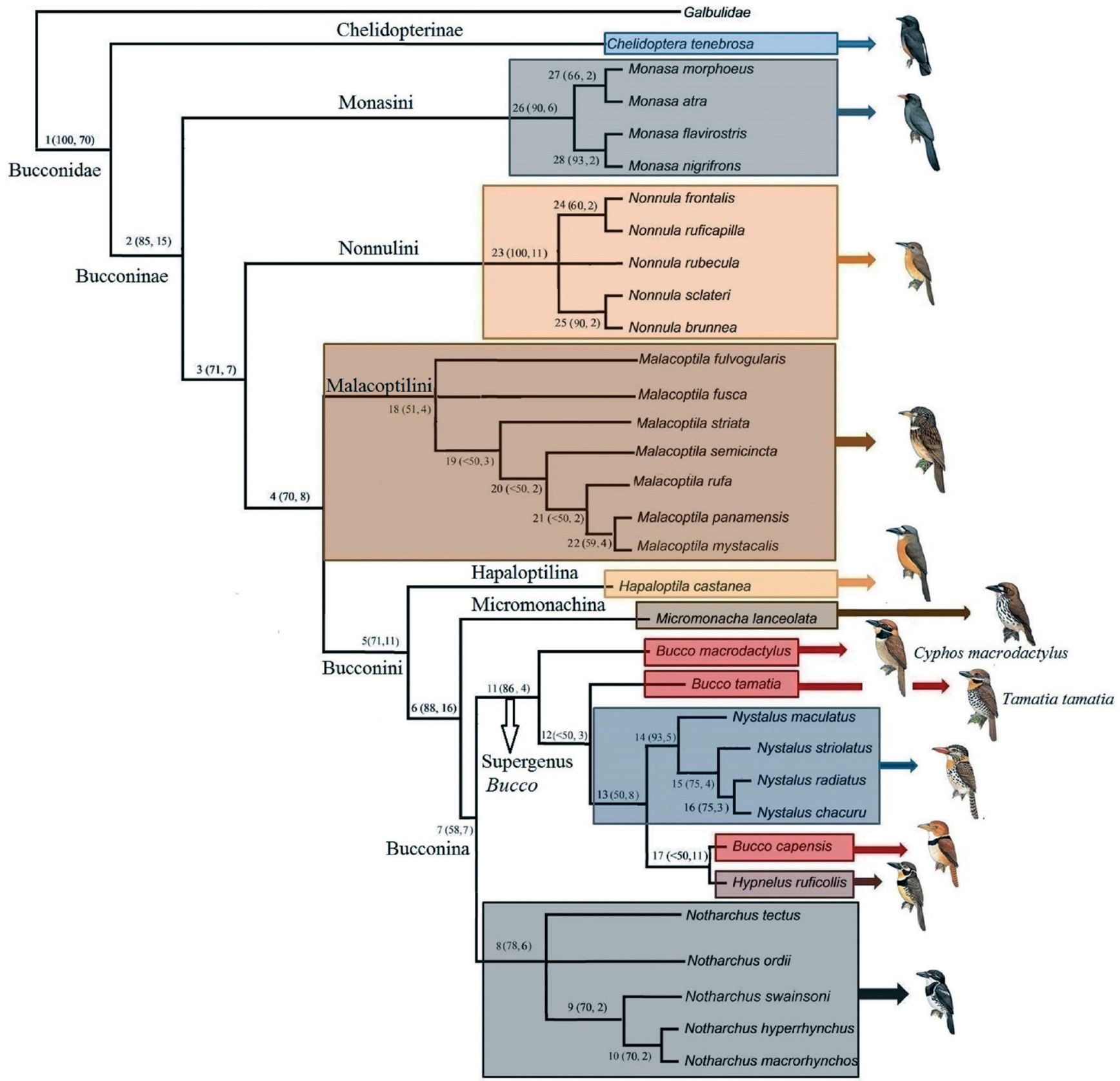

Figure 6. Phylogenetic relationships for Bucconidae species based on osteological data (Maximum Parsimony; Strict Consensus; 426 minimum steps; $\mathrm{Cl}=0,50$; $\mathrm{Rl}=0,72$ ). Numbers (1-28) indicate the nodes (branches). Values at the nodes in parentheses represent Bootstrap and Bremer indices, respectively. Red squares show the Bucco polyphyly. Illustrations of the Bucconidae species belong to the Handbook of Birds of the World - volume 7 - Bucconidae chapter (Rasmussen \& Collar, 2002). 
ally found in the second-growth forest galleries (Sick, 1997; Rasmussen \& Collar, 2002). Witt (2004) demonstrated that Nonnula is the most divergent genus of puffbirds based on molecular data and, therefore, the genus is the most basal in the Witt (2004) phylogeny. Considering the (subjective) degree of distinctness of Nonnula compared to Monasa, and the remaining Bucconinae, we opted to place Nonnula in the tribe Nonnulini. Although the position of N. rubecula is unclear, the results of the osteological analysis highly supported the arrangement (Nonnula ruficapilla [Tschudi, 1844]/Nonnula frontalis [Sclater, 1854]) (Nonnula sclateri Hellmayr, 1907/Nonnula brunnea Sclater, 1881). The topology corroborates the taxonomic history based on plumage similarity and distribution. Plumage is very similar among $N$. sclateri, N. brunnea, and $N$. rubecula. They are also sympatric in the southwest Amazon Basin and they have been historically considered closely related, whereas $N$. sclateri has been considered a race of $N$. brunnea (Rasmussen \& Collar, 2002). Plumage is similar between the allopatric $N$. ruficapilla and $N$. frontalis, and they have at times also been treated as conspecific (Rasmussen \& Collar, 2002). Although N. amaurocephala was not included in the present study, it is traditionally considered closely related to N. ruficapilla and $N$. frontalis (Rasmussen \& Collar, 2002). Therefore, the latter three species are considered a superspecies in the classification proposed here.

High support indices (branch 4, Fig. 6) and 10 synapomorphies suggest a sister relationship between Malacoptila Gray, 1841 and the tribe Bucconini: the proc. lacrimalis os frontale is short (Fig. 1, 3, 0-1); the medial concavity in the fissura zona flexoria craniofacialis is deep (Fig. 1, 5, 0-1); the ventral portion of the proc. orbitalis os lacrimale is long, narrow, medially curved and reaching the arcus jugalis (Fig. 2, 31, 2-0); the ventral portion os ectethmoidale is triangular in shape (Fig. 3, 33, 2-3); the foramem orbitonasalis lateralis is vestigial $(36,1-0)$; the fossa choanalis is long (Fig. 3, 57, 1-0); the proc. pterigoideus of the os palatinum is short (Fig. 3, 61, 2-1); the ala postacetabularis ilii is large (Fig. 5, 88, 2-1); the proc. dorsalis terminalis ischia is medially large and the apex is sharp (Fig. 5, 103, 1-0) and the proc. interclavicularis is rounded $(117,2-1)$. Five synapomorphies grouped the species of Malacoptila: the ventral portion of the proc. orbitalis os lacrimale is long, narrow, but straight (Fig. 2, $31,0-1)$; the fossa ventralis os palatinum is deep and long $(58,2-3)$; the foramen ilioschium is $60 \%$ of the total length of the synsacrum (Fig. 5, 92, 0-1); the incisura lateralis or fenestra lateralis with equal length to the incisura medialis or fenestra medialis os sternum $(113,0-1)$ and the tuberculum on the dorsal surface os metacarpale is vestigial $(126,1-0)$. They also exhibit major similarities with regard to plumage (white moustaches and the rear, flanks, and bellies are streaked) and DNA, and historically, there is no controversy about Malacoptila monophyly (Sick, 1997; Rasmussen \& Collar, 2002; Ferreira et al., 2016). Therefore, the inclusion of Malacoptila in the tribe Malacoptilini is prudent. The osteological characters were not adequate for the elucidation of the relationship of $M$. fusca with the other species. However, according to Ferreira et al.
(2016), the species is most closely related to Malacoptila semicincta Todd, 1925 based on four concatenated genes (Bayesian Inference). Although the support indices have low values, the other species are grouped based on four synapomorphies (branch 19, Fig. 6). The hypothesis provides high resolution information for the other species of Malacoptila, but they have low support index values, excluding the Malacoptila mystacalis (Lafresnaye, 1850)/Malacoptila panamensis Lafresnaye, 1847 branch. Historically, the two species have been considered conspecific, since they exhibit similar plumage and behavior characteristics and they are sympatric in the Andes of Colombia with Malacoptila fulvogularis Sclater, 1854 (Rasmussen \& Collar, 2002). Malacoptila mystacalis is missing in the molecular analysis of Ferreira et al. (2016) and they concluded that M. panamensis is a sister-group of all Malacoptila species, excluding M. fulvogularis. Such a topology was not observed in our analysis. However, both molecular (Ferreira et al., 2016) and osteological hypotheses demonstrated that $M$. fulvogularis is a sister taxon of the other Malacoptila species. Even more notable, Malacoptila striata (Spix, 1824), which is restricted to the Atlantic forest of Brazil, is related most closely with species distributed in the Amazon Basin based on both osteological and molecular data (Ferreira et al., 2016). Actually, the topology of Malacoptila presented herein is inconsistent with common distribution and historical taxonomy (excluding the cases of M. mystacalis and M. panamensis), with some inconsistency with molecular phylogeny (Ferreira et al., 2016) and most of the branches have low support indices and few synapomorphies. In most respects, the relationships within Malacoptila remain inconsistent with molecular data.

Node support (71, 11, branch 5, Fig. 6) and 14 synapomorphies unite the Hapaloptila/Micromonacha/ Notharchus/Bucco/Nystalus/Hypnellus clade: the fossa temporalis is long ( $90 \%$ of the lateral portion of the skull and medially close to each other) (Fig. 2, 6, 0-1); the proc. maxillaris os nasale is narrow (bar-shaped) (Fig. 2, 42, 1-2); the proc. maxillaris of the os palatinum is laterally large (Fig. 3, 51, 1-0); the proc. rostrodorsalis os palatinum is vestigial $(55,1-0)$; the fossa choanalis is vestigial (narrow) (Fig. 3, 57, 0-2); the crista ventralis os palatinum is prominent and large (Fig. 2, 62, 1-2); the crista dorsalis os pterigoideus is short and dorsally large (Fig. 2, 64, 1-2); the rostral apex of the ossa mandibulae (os dentale) is curved (Fig. 4, 73, 2-1); the pars simphisialis mandibulae is short (about $40 \%$ of the total length of the mandible) (Fig. 4, 75, 2-1); the fonticuli lateralis of ala preacetabularis is present $(90,1-0)$; the crista spinosa synsacri is narrow and short, but prominent $(93,1-2)$; the proc. craniolateralis is longer (25 to $30 \%$ of the total length of the os sternum) (Fig. 5, 109, 1-2); the width of the crista deltopectoralis os humerus is large $(121,2-1)$; the rostral apex of the rhamphotheca is ventrally and strongly curved (134, 1-2).

The Bucconini clade has high support indices (branch 7, Fig. 6) and there are eight synapomorphies: the lateral extension of the zona flexoria craniofacialis is equal to the lateral extension os frontale (Fig. 1, 4, 1-0); the medial concavity in the fissura zona flexoria craniofacialis 
is deep and long (more caudally extended) (Fig. 1, 5, 1-2); the proc. esquamosalis is the longest among puffbirds (either $90 \%$ of this distance or reaching the arcus jugalis) (Fig. 2, 10, 0-1); the proc. orbitalis os lacrimale is laterally large with sharp projection in the laterodorsal extremity (Fig. 2, 29, 0-1); the lateral tuberculum on the caudal extremity of the arcus jugalis is prominent (Fig. 2, 67, 2-1); the condylus medialis os quadratum is longer and larger (Fig. 3, 70, 1-2); the cotyla lateralis and the cotyla caudalis mandible are fused to each other and shallow (Fig. 4, $82,1-2)$; the caudal tuberculum in the lateral surface of ala preacetabularis is vestigial or absent $(96,1-0)$; the expansion carinae into trabecula medialis is short and crest in shape (114, 2-1). Ladeira \& Höfling (2007) also observed numerous skull similarities among Bucco/Notharchus/ Nystalus and they have strong and long beaks, in addition to large heads (Rasmussen \& Collar, 2002). Therefore, we classified the group as tribe Bucconini.

Hapaloptila Sclater, 1881 and Micromonacha Sclater, 1881 are sister-groups of the subtribe Bucconina. All the arrangements above are robust based on the support indices (branches 5 and 6, Fig. 6) and high numbers of synapomorphies. Hapaloptila castanea (Verreaux, 1866) can be distinguished from the other puffbirds based on the following apomorphies: the os frontale reaches $50 \%$ of the width of os parietale $(2,1-0)$; the proc. lacrimalis os frontale is laterally large $(3,1-2)$; the proc. orbitalis os lacrimale is straight and large (Fig. 2, 31, 0-3); the proc. pterigoideus is vestigial (tubercular) $(61,1-2)$; the proc. medialis mandible is short ( $8 \%$ of the total length of the mandible) $(80,2-1)$; the crista iliaca dorsalateralis is prominent and long $(95,1-2)$; the caudal tuberculum of the ala preacetabularis is prominent and large (triangular shape) $(96,1-3)$; the trabecula intermedia of the os sternum reaches $50 \%$ of the total length of the os sternum $(112,0-1)$; the proc. interclavicularis is rounded, large and more prominent $(117,1-2)$; and in the ossa digitorum pedis the $4^{\text {th }}$ toe is longer than the $2^{\text {th }}(135,1-0)$. In addition, Hapaloptila castanea (Verreaux, 1866) is the only puffbird known to live in highlands. It is also the largest puffbird $(25 \mathrm{~cm})$ and it has some unique features on its plumage: a black band across the forehead, the upper parts and the tail are dark-brownish grey and the under parts are orange-rufous (Rasmussen \& Collar, 2002).

Micromonacha lanceolata (Deville, 1849) is the smallest puffbird $(13 \mathrm{~cm})$ and the puffbird with the shortest tail (Rasmussen \& Collar, 2002). The species can be diagnosed based on the proeminentia cerebelaris tubercular but laterally large (Figs. 2 and 3, 12, 1-2), the proc. lacrimalis is filiform and long (Fig. 2, 24, 1-0), the apertura nasi ossea is long (20\% of the upper jaw) (Fig. 2, 45, 2-1), the proc. maxillaris os palatinum is narrow $(51,0-1)$, the angulus rostromediais os palatinum not fused to each other (54, 1-0), the fossa choanalis is short and rounded (Fig. 3, 57, 2-1), the crista dorsalis os pterigoideus is short (Fig. 2, 64, 2-1), the fonticuli lateralis ala preacetabularis is long and large $(91,2-1)$, the foramen ilioschium reaches $60 \%$ of the synsacrum $(92,0-1)$, the crista spinosa synsacri is narrow and short $(93,2-1)$, the proc. ventralis terminalis ischii reaches between $25 \%$ to $20 \%$ of the synsacrum
(100, 1-0), the proc. dorsalis terminalis ischii is large with its apex rounded $(103,0-4)$; the spina interna rostri reaches $20 \%$ of the total length of the os sternum (106, 1-2), the crista deltopectoralis os humerus is short (it reaches $20 \%$ of the total length of the humerus) $(120,1-0)$, the crista deltopectoralis os humerus is reduced $(121,1-0)$ and the apex of the ramphotheca is slightly curved (134, 2-1).

Therefore, the large sets of apomorphies (mentioned above) in addition to their phylogenetic positions and the unique characteristics in both Hapaloptila and Micromonacha indicate ancient cladogenesis. Therefore, they are both considered monotypic subtribes in the classification proposed here.

The supergenus Bucco is justified by high support indices (branch 11, Fig. 6) and six synapomorphies: the dorsal portion of the os ectethmoidale is long, but not in contact with the os lacrimale (34, 2-1); the proc. maxillaris os nasale is narrow (bar-shaped) (Fig. 2, 42, 3-2); the facies dorsalis of the maxilla (upper jaw) is prominent and rounded (Fig. 2, 43, 0-1); the proc. transpalatinus os palatinum is vestigial (Fig. 3, 56, 1-0); the fonticuli lateralis of ala preacetabularis is long and large (Fig. 5, 90, 0-1) and the length of the incisura lateralis or fenestra lateralis is equal to the length of the incisura medialis or fenestra medialis of the os sternum (113, 0-1).

Notably, the traditionally accepted Bucco (Remsen et al., 2020) is polyphyletic (branch 11, Fig. 6: red square), as well as in Rasmussen \& Collar (2002) based on the findings of Witt (2004). Both B. macrodactylus Spix, 1824 and B. tamatia (Gmelin, 1788) appeared as the earliest diverging lineages within Bucconini (branches 12 and 13, respectively, Fig. 6) and Bucco capensis is closely related to Nystalus and Hypnellus ruficollis (branches 13 and 17, Fig. 6).

Although the bootstrap index is low, 12 synapomorphies support the relationship between Bucco capensis and Hypnellus ruficollis (branch 17, Fig. 3) strongly: the sharp projection of the proc. ventralis os lacrimale is not parallel to the proc. ventralis os ecthtmoidale (Fig. 2, $26,0-1)$; the ventral portion of the proc. orbitalis os lacrimale is long, narrow and straight (Fig. 2, 31, 0-1); the tuberculum in the rostroventral portion os ectethmoidale is long and dorsally larger (Fig. 2, 35, 2-3); the proc. maxillaris of the os palatinum is thick (Fig. 3, 51, 0-2); the pars simphisialis mandible is short (about $30 \%$ of the total length of the mandible) (Fig. 4, 75, 1-2); the fossa aditus canalis neurovascularis mandible is long and deep (Fig. 4, 78, 1-2); the caudal tuberculum in the lateral surface of ala preacetabularis is prominent and large $(96,1-2)$; the spina interna rostri is reduced ( $20 \%$ of the total length of os sternum) (Fig. 5, 106, 0-2) and narrow (laterally flattened) (Fig. 5. $107,1-0)$; the incisura lateralis or fenestra lateralis is longer to the incisura medialis or fenestra medialis os sternum (Fig. 5, 113, 1-0); the proc. interclavicularis is rounded, large and more prominent $(117,1-2)$ and the os tarsometatarsus is longer than the os femoris (Fig. 5, 133, 1-2). Bucco capensis is closely related to $\mathrm{H}$. ruficollis; however, we considered them distinct genera because of the high number of autapomorphies in their historical taxonomy. In addition, they vary from each other based on plumage, ecology, and behavior (Sick, 1997; Rasmussen \& Collar, 2002). 
Bucco tamatia is the sister-group of all Bucconini species (branch 12, Fig. 6) with high support indices and four synapomorphies: the concavity in the fissura zona flexoria craniofacialis deep and short (Fig. 1, 5, 2-1); the extension of the proc. postorbitalis in relation to the jugal bar is long, reaching the lateral portion of the arcus jugalis (Fig. 2, 15, 1-2); the spina interna rostri is large (Fig. 5, $107,0-1)$ and its crista dorsalis is absent $(108,0-1)$.

The type species of Bucco is B. capensis Linnaeus, 1766, therefore, "Bucco" macrodactylus (Spix, 1824) must be assigned to a different genus if we maintain Nystalus and Hypnelus. Two genus names are available for macrodactylus, with Cyphos Spix, 1824 having priority over Argicus Cabanis \& Heine, 1863. We, therefore, suggest the reinstatement of the original combination Cyphos macrodactylus Spix, 1824. Subsequently, Bucco tamatia also needs to be considered as a distinct genus based on the topology and three apomorphies. Rasmussen \& Collar (2002) have applied the genus Nystactes Gogler, 1827 to it, however, the name could be a synonym of Capito. Regardless, Tamatia Cuvier, 1817 (type species Tamatia maculata Cuvier = Bucco tamatia Gmelin) would have priority over Nystactes ("Tamatia" in Cuvier [1798] was not used in a generic sense; in Rafinesque [1815] it is a nomen nudum). Therefore, we suggest the combination Tamatia tamatia (Gmelin). "Bucco" noanamae was not included in the phylogenetic analyses presented herein but appears as a sister group of T. tamatia (Rasmussen \& Collar, 2002). Therefore, we included it in Tamatia as well.

Nystalus is the sister group of B. capensis/Hypnelus ruficollis (Wagler, 1829) with high support nodes and 10 synapomorphies: the fossa temporalis is long and fused to each in the medial portion of the skull (Fig. 2, $6,1-2)$; the proc. orbitalis os lacrimale is larger laterally but shorter dorsally (Fig. 2, 29, 1-0); the dorsal portion os ectethmoidale is short, not in contact with the os lacrimale (Fig. 2, 34, 1-0); the tuberculum in the rostroventral portion os ectethmoidale is long (more prominent) (Fig. 2, $35,1-2$ ); the caudal portion of the upper jaw (os nasale and os maxillare) is dorsally large (about $70 \%$ of the width of the upper jaw) (Fig. 2, 40, 0-1); the proc. transpalatinus os palatinum is long and sharp (Figs. 2 and 3, 56, 0-2); the rostral portion of the os palatinum is larger than its caudal portion (Fig. 3, 59, 0-3); the ala postacetabularis ilii is narrow (Fig. 5, 88, 1-0); the caudal tuberculum in the lateral surface of ala preacetabularis is prominent (Fig. 5, $96,0-1)$ and the length of spina interna rostri is $10 \%$ of the total length of os sternum (Fig. 5, 106, 1-0).

Nystalus Cabanis \& Heine, 1863 is a valid genus with high node support (93, 5, branch 14, Fig. 6) and six synapomorphies: the tuberculum in the rostroventral portion of the proc. postorbitalis is vestigial (Fig. 2, 16, 1-0); the facies dorsalis of the maxilla (upper jaw) is prominent and sharp (Fig. 2, 43, 1-2); the fossa ventralis os palatinum is deep and long and larger than other puffbirds (Fig. 3, $58,2-4)$; the proc. orbitalis os quadratum is the narrowest and longest of all puffbirds $(71,2-3)$; the proc. dorsalis terminalis ischii is narrow in it all extension and the apex is pointed (Fig. 5, 103, 0-1) and the dorsoventral depth carina sterni is narrow $(115,0-1)$. Although Nystalus mac- ulatus (Gmelin, 1788) is sympatric with Nystalus chacuru (Vieillot, 1816) in eastern South America, N. maculatus is a lineage isolated from other Nystalus species. Nystalus striolatus is historically closely related to $N$. radiatus (Rasmussen \& Collar, 2002). However N. chacuru together with Nystalus radiatus (Sclater, 1854) are the sister group of the Nystalus striolatus complex based on the results of our osteological analyses with high support indices and a high number of synapomorphies. Whitney et al. (2013) have recently suggested the $N$. striolatus complex to be composed of three cryptic species, which has been adopted by Piacentini et al. (2015), and partially by Remsen et al. (2020). We include N. obamai and N. striolatus S.s. in our classification because they have been considered the most closely related species and they exhibit morphological, distributional, and behavioral similarities within the complex (Whitney et al., 2013).

Notharchus Cabanis \& Heine, 1863 is the sister-group to other Bucconina and a monophyletic genus with high support indices (78, 6, branch 8 , Fig. 6 ) and eight synapomorphies: the fossa temporalis is the longest (fused to each in the medial portion of the skull) of all puffbirds (Figs. 1 and 2, 6, 1-2); the proc. postorbitalis is caudally curved and wide (Figs. 1 and 2, 14, 1-2); the proc. lacrimalis is thick (Fig. 2, 24, 1-2); the fossa ventralis os palatinum is deep, long and larger than other puffbirds (58, 2-4); the proc. dorsalis terminalis ischii is narrow in it all extension and the apex is pointed (Fig. 5, 103, 0-1); the proc. craniolateralis is long ( $20 \%$ of the total length os sternum) (Fig. 5, 109, 2-1); the dorsoventral depth carina sterni is the narrowest (reduced) among all puffbirds (115, 0-2) and the total length os tarsometatarsus is $75 \%$ the total length os femoris (Fig. 5, 133, 1-0). The genus has been historically considered monophyletic. The plumage is primarily black and white with black masks, white heads, in addition to black caps and barred flanks. They also have the largest bodies among the puffbirds (except H. castanea) and they are sympatric in the northern portion of South America, excluding Notharchus macrorhynchus (Gmelin, 1788), and N. swainsoni (Gray, 1846) in the Atlantic forest (Sick, 1997; Rasmussen \& Collar, 2002). Notharchus tectus (Boddaert, 1783) has distinct plumage (black cap with white speckles and scapular white patches) and a short beak, and has been considered to be belong to Bucco in some cases (Rasmussen \& Collar, 2002), so that the placement of $N$. tectus as the sister-taxon to the other Notharchus is consistent with such morphological divergence. Although the position of $N$. ordii remains unclear based on the results of the osteological analysis, the historical taxonomy and plumage similarity suggest proximity with Notharchus swainsoni and it has historically been considered closely related to Notharchus pectoralis (Rasmussen \& Collar, 2002). The osteological data suggest the Notharchus swainsoni/Notharchus macrorhynchus/Notharchus hyperrhynchus (Sclater, 1856) grouping, although with low node support and three synapomorphies. In addition, together with N. pectoralis (not included in this analysis), the grouping is more consistent when plumage similarity and historical taxonomy are considered (Sick, 1997; Rasmussen \& Collar, 
2002). Notharchus swainsoni has often been considered conspecific with N. hyperrhynchus; however, Alvarenga et al. (2002) considered N. swainsoni a valid species, based on its distinct morphological characters including its smaller size, and it is a geographically disjunct species distributed in the Atlantic Forests of Brazil, Argentina, and Paraguay. The topology from the analysis presented herein corroborates the Alvarenga et al. (2002) hypothesis for N. swainsoni. Two synapomorphies support the N. macrorhynchus/N. hyperrhynchus clade, which corroborates the historical taxonomy, since they were considered conspecifics until recently (Rasmussen \& Collar, 2002; Remsen et al., 2020). They were considered distinct species by Remsen et al. (2020) and they are allopatric in distribution with plumage differences between each other (Rasmussen \& Collar, 2002). In addition, we observed six autapomorphies of $N$. hyperrhynchus, which corroborates its validity. Conversely, N. macrorhynchus was the unique species without a single autapomorphy amongst all the Bucconidae species. Therefore, N. macrorhynchus should be taxonomically investigated using other characters as sources of data.

Finally, here, we propose five novel diagnosed taxa in the family-group to integrate the phylogenetic information into a linear classification in the Bucconidae (Table 2).

Chelidopterinae, new subfamily: Type and only genus: Chelidoptera Gould, 1837

Diagnosis: This subfamily can be distinguished by the proc. lacrimalis os frontale laterally large; proeminentia cerebelaris tubercular, laterally large; proc. lacrimalis thick, medial curvature, large, lateral concavity; proc. orbitalis os lacrimale lateromedially large, medial curvature; proc. maxillaris os nasale narrow (bar-shaped), laterally large; fossa ventralis os palatinum deep, long, large; caudal portion os palatinum larger than rostral; fossa caudalis mandible narrow, shallow; proc. dorsalis terminalis ischii 5\% synsacrum; apex ramphotheca long curvature.

Monasini, new tribe: Type and only genus: Monasa Vieillot, 1816

Diagnosis: This tribe can be distinguished by the depressio frontalis shallow; os frontale $50 \%$ os parietale; os ectethmoidale short/sharp/long; tuberculum os ectethmoidale prominent; proc. maxillaris os nasale bar-shaped; os tibiotarsus $40 \%$ longer os femoris.

Nonnulini, new tribe: Type and only genus: Nonnula Sclater, 1854

Diagnosis: This tribe can be distinguished by the os frontale $20 \%$ os parietale; proc. suprameaticus long; proeminentia cerebelaris tubercular, laterally large; proc. postorbitalis reduced, proc. orbitalis os lacrimale reduced, triangular-shaped; proc. transpalatinus long, sharp; tuberculum proc. opticus absent; proc. medialis mandible short (8\% mandible); fossa caudalis mandible narrow, shallow; caudal tuberculum ala preacetabularis prominent, large;
Table 2. Phylogenetic classification of the Bucconidae Horsfield, 1821. The term incertae sedis indicates taxa that were part of a polytomy in the most parsimonious tree (Fig. 6).

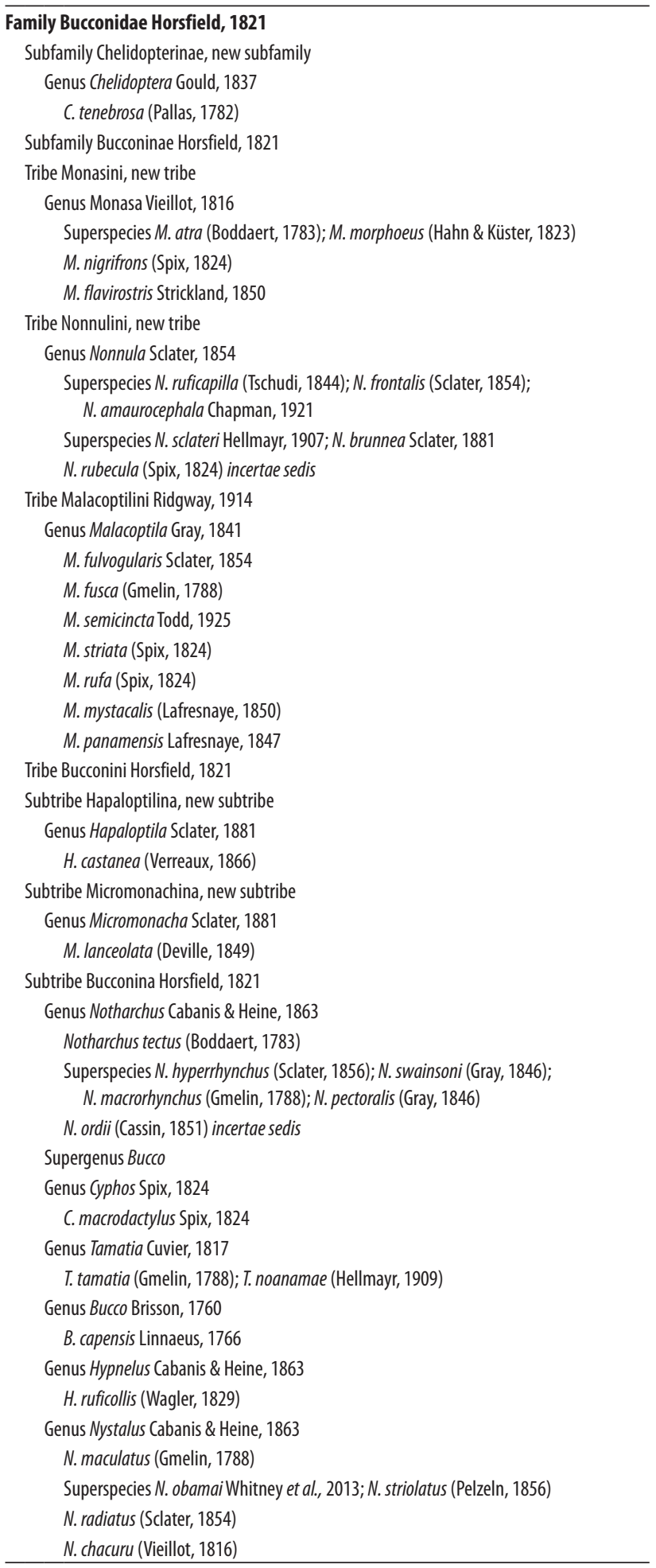

trabecula lateralis os sternum $70 \%$ os sternum, os tarsometatarsus longer os femoris.

Hapaloptilina, new subtribe: Type and only genus: Hapaloptila Sclater, 1881

Diagnosis: This subtribe can be distinguished by the os frontale $50 \%$ os parietale; proc. lacrimalis os frontale lat- 
erally large; proc. orbitalis os lacrimale straight/large; proc. pterigoideus vestigial/tubercular; proc. medialis mandible short ( $8 \%$ mandible); crista iliaca dorsalateralis prominent/long; caudal tuberculum ala preacetabularis prominent/large (triangular); trabecula intermedia os sternum $50 \%$ os sternum; proc. interclavicularis rounded/large/ more prominent; ossa digitorum pedis: $4^{\text {th }}$ longer $2^{\text {th }}$.

Micromonachina, new subtribe: Type and only genus: Micromonacha Sclater, 1881

Diagnosis: This subtribe can be distinguished by the proeminentia cerebelaris tubercular, large; proc. lacrimalis filiform/long; apertura nasi ossea long (20\% upper jaw); proc. maxillaris os palatinum narrow; angulus rostromediais os palatinum not fused to each other; fossa choanalis short; crista dorsalis os pterigoideus short; fonticuli lateralis ala preacetabularis long/large; foramen ilioschium 60\% synsacrum; crista spinosa synsacri narrow/short; proc. ventralis terminalis ischii $25 \%$ to $20 \%$ synsacrum; proc. dorsalis terminalis ischii large/apex rounded; spina interna rostri $20 \%$ os sternum; crista deltopectoralis os humerus short (20\% humerus); crista deltopectoralis os humerus reduced; apex ramphotheca slightly curved.

\section{CONCLUSION}

The present analysis revealed a well-resolved and strongly supported phylogeny, with high terminal taxa resolutions (topological dichotomies) for all the Bucconidae species, save for the ambiguous relationships observed in Notharcus ordii (Cassin, 1851), Malacoptila fusca (Gmelin, 1788), and Nonnula rubecula (Spix, 1824). In addition, the present topology is hardly in conflict with existing literature.

The analysis also reveals high numbers of apomorphies, which indicate the validity of all genera currently recognized. However, the major arrangement reveals that Bucco Brisson, 1760 is a polyphyletic genus, so that Tamatia and Cyphos are revalidated. Consequently, the present study demonstrates that osteology is an adequate source of data for elucidating most of the relationships within the Bucconidae.

The major contribution of the present study is a proposal for classification based on a modern analysis for the first time of the genus Bucconidae based on osteological characters. The proposal could facilitate studies focusing on the taxonomy, paleontology, evolution, biogeography, and ecology of these poorly understood Neotropical birds.

\section{ACKNOWLEDGMENTS}

We thank all the staff of the museums for providing specimens or assistance with collections in loco. We also thank to the American Journal Experts and Editage for English language editing and the reviewers for their thoughtful comments and efforts towards improving this article. Funding was provided by the Brazilian National
Council for Scientific and Technological Development (CNPq 483431/2011-7 to SRP).

\section{REFERENCES}

Alvarenga, H.; Höfling, E. \& Silveira, L.F. 2002. Notharchus swainsoni (Gray) (Bucconidae) é uma espécie válida. Ararajuba, 10:73-77.

Baumel, J.\&Witmer, L.M. 1993. Osteologia. In:Baumel, J.; King, A.S.; Breazile, J.E.; Evans, H.E. \& Vanden Berge, J.C. (Eds.). Handbook of avian anatomy: Nomina anatomica avium. Cambridge, Nuttall Ornithological Club. p. 45-132.

Cuvier, G. 1798. Tableau élémentaire de I'histoire naturelle des animaux. Paris, Baudouin. p. j-xvj [= 1-16], 1-710, pl. I-XIV [=1-14].

Duarte, S.R. 2015. Filogenia molecular do gênero Nystalus (Bucconidae, Aves): Enfoque na estruturação populacional em N. maculatus e N. chacuru. Master dissertation. Brasilia, Universidade de Brasília.

Ferreira, M.; Aleixo, A.; Ribas, C.C. \& Santos, M.P.D. 2016. Biogeography of the neotropical genus Malacoptila (aves: Bucconidae): The influence of the andean orogeny, amazonian drainage evolution and palaeoclimate. Journal of Biogeography, 43: 1-12.

Goloboff, P.A.; Farris, J.S. \& Nixon, K.C. 2008. TNT, a free program for phylogenetic analysis. Cladistics, 24: 774-786.

Höfling, E. \& Alvarenga, H.M.F. 2001. Osteology of the shoulder girdle in the Piciformes, Passeriformes and related groups of birds. Zoologischer Anzeiger, 240: 196-208.

International Comission on Zoological Nomenclature (ICZN). 1999. International Code of Zoological Nomenclature. London, International Trust on Zoological Nomenclature.

Ladeira, L.M.C.E.B. \& Höfling, E. 2007. Osteologia craniana de bucconidae. Boletim do Museu Paraense Emílio Goeldi, Série Ciências Naturais, 2: 117-153.

Piacentini, V.Q.; Aleixo, A.; Agne, C.E.; Mauricio, G.N.; Pacheco, J.F.; Bravo, G.A.; Brito, G.R.R.; Naka, L.N.; Olmos, F.; Posso, S.R.; Silveira, L.F; Betini, G.S.; Carrano, E.; Franz, I.;Lees, A.C.;Lima, L.M.; Pioli, D.; Schunck, F; Amaral, F.R.; Bencke, G.A.; Cohn-Haft, M.; Figueiredo, L.F.A; Straube F.C. \& Cesari, E. 2015. Annotated checklist of the birds of brazil by the Brazilian Ornithological Records Committee. Revista Brasileira de Ornitologia, 23: 91-298.

Posso, S.R. \& Donatelli, R.J. 2005. Skull and mandible formation in the cuckoos (Aves, Cuculidae): Contributions to the nomenclature in avian osteology and systematics. European Journal of Morphology, 42: 163-172.

Rafinesque, C.S. 1815. Analyse de la nature or tableau de l'univers et des corps organisés. Palerme, Aux dépens de l'auteur.

Rasmussen, P.C. \& Collar, N.J. 2002. Family Bucconidae (puffbirds). In: Del Hoyo, J.; Elliott, A. \& Sargatal, J. (Eds.). Handbook of the birds of the world, Barcelona, Lynx Edicions. v. 7, p. 102-138.

Remsen Júnior, J.V.; Areta, J.I.; Bonaccorso, E.; Claramunt, S.; Jaramillo, A.; Pacheco, J.F; Robbins, M.B.; Stiles, F.G.; Stotz, D.F. \& Zimmer, K.J. 2020. A classification of the bird species of South America. American Ornithological Society. AAvailable at: http://www.museum.lsu.edu/ Remsen/ SACCBaseline.htm. Access in: 02/06/2020.

Sick, H. 1997. Ornitologia brasileira. Rio de Janeiro, Nova Fronteira.

Steinbacher, J. 1937. Anatomische untersuchungen über die systematische stellung der Galbulidae und Bucconidae. Archiv für Naturgeschichte, Neue Folge, 6: 417-515.

Whitney, B.M.; Piacentini, V.Q.; Schunck, F.; Aleixo, A.;Sousa, B.R.S. \& Silveira, L.F. 2013. A name for striolated puffbird west of the rio madeira with revision of the Nystalus striolatus (Aves: Bucconidae) complex. In: Del Hoyo, J.; Elliott, A.; Sargatal, J. \& Christie, D. (Eds.). Handbook of the birds of the world. Special volume. New species and global index. Barcelona, Lynx Edicions.

Witt, C.C. 2004. Rates of molecular evolution and their application to neotropical avian biogeography. PhD. Thesis. Baton Rouge, Faculty of the Louisiana State University and Agricultural and Mechanical College. 


\section{APPENDIX 1}

\section{List of the osteological characters (1-135) and their respective states of variations (multistates from 0 to 4).}

1. Depressio frontalis: (0) vestigial; (1) shallow; (2) deep.

2. Lateral length os frontale (orbital portion): (0) $50 \%$ of the lateral length os parietale; (1) $30 \%$ of the lateral length os parietale; (2) $20 \%$ of the lateral length os parietale.

3. Proc. lacrimalis os frontale: (0) vestigial; (1) short; (2) large (laterally prominent).

4. Lateral extension of the zon flexoria craniofacialis: (0) equal to the lateral extension os frontale; (1) shorter than the lateral extension os frontale.

5. Medial concavity in the fissura zona flexoria craniofacialis: (0) shallow; (1) deep; (2) deep and long (more caudally extended).

6. Fossa temporalis: (0) short ( 60 to $70 \%$ of the lateral portion of the skull and medially distant to each other); (1) longer ( $90 \%$ of the lateral portion of the skull and medially close to each other); (2) longest (fused to each in the medial portion of the skull).

7. Ventral portion of the fossa temporalis: (0) short and shallow; (1) long and deep.

8. Proc. paraoccipitalis: (0) vestigial; (1) long and large.

9. Proc. esquamosalis: (0) vestigial; (1) long and narrow.

10. Proc. esquamosalis: (0) long (40 to $70 \%$ of the distance to the arcus jugalis); (1) longest (either $90 \%$ of this distance or reaching the arcus jugalis).

11. Proc. suprameaticus: (0) short (either tubercular or vestigial); (1) long.

12. Proeminentia cerebelaris: (0) large and prominent; (1) tubercular and narrow; (2) tubercular but laterally larger than 1.

13. Dorsomedial portion of the proc. post orbitalis: (0) narrow; (1) large.

14. Shape of the proc. postorbitalis: (0) narrow and straight; (1) wider laterally and curved caudally at its apex; (2) caudally curved and wider than $1^{\text {st }}$ condition.

15. Extension of the proc. postorbitalis in relation to the jugal bar: (0) short; (1) longer, close to arcus jugalis; (2) longest, reaching the lateral portion of the arcus jugalis.

16. Tuberculum in the rostroventral portion of the proc. post orbitalis: (0) vestigial; (1) short; (2) long (more prominent).

17. Fossa lateralis os parasphenoidale: (0) present; (1) absent.

18. Proc. lateralis os parasphenoidale: (0) large and short; (1) reduced (tubercular form); (2) thick e long.

19. Canalis semicircularis os parasphenoidale: (0) narrow; (1) ventrally rounded and dorsally narrow.

20. Rostral projection os parasphenoidale: (0) long and narrow; (1) short and large.

21. Crista medialis of the lamina parasphenoidale: (0) present; (1) absent.

22. Proc. basipterygoideus: (0) absent; (1) present.

23. Suture between os frontale and os lacrimalis: (0) long; (1) short; (2) shortest.

24. Proc. lacrimalis: (0) filiform, dorsally reaching arcus jugalis; (1) idem 0, bar-shaped, reaching medially arcus jugalis; (2) thicker than 1; (3) thicker than 1, but medially curved and the proc. lacrimalis is even larger and it presents a lateral concavity.

25. Proc. supraorbitalis os lacrimale: (0) dorsally large and rostrally sharp; (1) dorsoventrally narrow (rectangular in shape) and it presents a short projection to the zona flexoria craniofacialis.

26. Sharp projection of the proc. ventralis os lacrimale parallel to the proc. ventralis os ecthtmoidale: (0) present; (1) absent.

27. Ventral projection of the proc. dorsalis os lacrimale: (0) long and fusioned to the arcus jugalis; (1) short; (2) reduced (tubercular in shape).

28. Proc. orbitalis os lacrimale: (0) narrow and sharp; (1) lateromedially large; (2) larger and it presents a medially curvature close to os frontale; (3) reduced (triangular in shape); (4) laterally larger but dorsally short.

29. Proc. orbitalis os lacrimale: (0) larger laterally but short dorsally; (1) idem 1, but with sharp projection in the laterodorsal extremity.

30. Suture between os nasale and os lacrimale: (0) long; (1) short; (2) vestigial.

31. Ventral portion of the proc. orbitalis os lacrimale: (0) long, narrow, medially curved and reaching arcus jugalis; (1) long, narrow, but straight; (2) long, narrow, but sharp in its extremity; (3) straight and large.

32. Os ectethmoidale: (0) thin; (1) thick.

33. Ventral Portion os ectethmoidale: (0) short and sharp; (1) short and sharp, but longer (ventrally extending well beyond arcus jugalis); (2) idem 3, but narrower; (3) triangular in shape.

34. Dorsal portion os ectethmoidale: (0) short, not in contact with the os lacrimale; (1) longer than 0, but not in contact with the os lacrimale; (2) longest (in contact with os lacrimale) and large.

35. Tuberculum in the rostroventral portion os ectethmoidale: (0) vestigial; (1) prominent; (2) longer than $1^{\text {st }}$ condition (more prominent); (3) longer than $1^{\text {st }}$ condition but dorsally larger.

36. Foramem orbitonasalis lateralis: (0) vestigial; (1) large.

37. Shape of the fenestra anteorbitalis (lateral view): (0) rounded; (1) triangular.

38. Upper jaw: (0) short (about 50 to $60 \%$ of the total length of the skull); (1) long (about $70 \%$ or more of the total length of the skull).

39. Rostrum maxillae (rostral apex os premaxillare): (0) not curved or slightly curved; (1) curved; (2) strongly curved and long.

40. Caudal portion of the upper jaw (os nasale and os maxillare): (0) dorsally short (about $50 \%$ of the width of the upper jaw); (1) dorsally large (about $70 \%$ of the width of the upper jaw); (2) larger than $2^{\text {nd }}$ condition (about $90 \%$ of the width of the upper jaw); (3) extremelly short (about $40 \%$ of the width of the upper jaw).

41. Proc. jugalis os maxillare: (0) vestigial; (1) narrow and long.

42. Proc. maxillaris os nasale: (0) thick and dorsally large; (1) thick, but dorsally narrow; (2) narrow (bar-shaped); (3) thin and but laterally larger.

43. Facies dorsalis of the maxilla (upper jaw): (0) not prominent and rounded; (1) prominent and rounded; (2) prominent and sharp.

44. Shape of the apertura nasi (nasalis) ossea: (0) narrow and straight; (1) oval; (2) rounded. 
45. Length of the apertura nasi (nasalis) ossea: (0) short (10 to $15 \%$ of the total length of the upper jaw); (1) long (20\% of the total length of the upper jaw); (2) longer (30\% or more of the total length of the upper jaw).

46. Crest in the ventral surface of the apertura nasi (nasalis) ossea: (0) not prominent and short; (1) prominent and long.

47. Tuberculum in the caudal portion of the apertura nasi (nasalis) ossea, close to fenestra antorbitalis: (0) vestigial; (1) prominent; (2) more prominent and sharp.

48. Concavity in the apertura nasi (nasalis) ossea: (0) shallow and narrow; (1) deep and rounded.

49. Caudal aperture between the nostril and fenestra antorbitalis: (0) narrow; (1) large.

50. Septum nasi (nasale) osseum: (0) completely ossified; (1) partially ossified (there is a small aperture in the dorsocaudal portion of the nostril); (2) partially ossified, but the aperture is larger.

51. Proc. maxillaris of the os palatinum: (0) laterally large; (1) laterally narrow; (2) laterally narrow, but dorsoventrally thick.

52. Pars lateralis os palatinum: (0) short; (1) long.

53. Fossa medialis os palatinum: (0) narrow; (1) large.

54. Fusion between the angulus rostromediais os palatinum: (0) absent; (1) present.

55. Proc. rostrodorsalis os palatinum: (0) vestigial; (1) short; (2) long.

56. Proc. transpalatinus os palatinum: (0) vestigial; (1) long; (2) long and sharp.

57. Fossa choanalis: (0) long; (1) short; (2) vestigial.

58. Fossa ventralis os palatinum: (0) shallow and short; (1) shallow and long; (2) deep and short; (3) deep and long; (4) deep and long, but larger.

59. Width of the caudal portion os palatinum in relation to the rostral portion: (0) caudal larger than rostral; (1) caudal equal to rostral; (2) caudal larger than rostral, but the portion caudal is larger (closer to arcus jugalis); (3) rostral larger than caudal.

60. Pars choanalis: (0) large and long; (1) narrow and short.

61. Proc. pterigoideus of the os palatinum: (0) long; (1) short; (2) vestigial (tubercular in shape).

62. Crista ventralis os palatinum: (0) vestigial; (1) prominent; (2) prominent, but even larger.

63. Proc. basipterygoideus: (0) medially in contact to each other (they are meeting in midline below); (1) there is no contact to each other.

64. Crista dorsalis os pterygoideus: (0) long; (1) short (restrict to the rostral portion of the os pterigoideus); (2) short and dorsally large; (3) short and dorsally large, but more prominent; (4) vestigial.

65. Dorsal protuberance on the medial region of arcus jugalis (in the contact area with the os lacrimale and the os ectethmoidale): (0) reduced (thin); (1) thick.

66. Ventral tuberculum on the caudal portion of the arcus jugalis: (0) present; (1) absent.

67. Lateral tuberculum on the caudal extremity of the arcus jugalis: (0) vestigial; (1) prominent; (2) larger and more prominent.

68. Fusion between the condylus caudalis and condylus lateralis os quadratum: (0) absent; (1) present.

69. Condylus lateralis os quadratum: (0) large and thick; (1) short and ventrally flattened.

70. Condylus medialis os quadratum: (0) short and laterally flattened; (1) long, more prominent and its ventral extremity is rounded; (2) longer and larger relative to condition n. 1; (3) longer and larger but thicker.

71. Proc. orbitalis os quadratum: (0) short; (1) short, but larger in its basal portion, sharp and more distant from os pterigoideus; (2) longer and narrower relative to condition n. 1; (3) narrowest and longest.

72. Tuberculum on the dorsal surface of the proc. oticus os quadratum: (0) absent; (1) present.

73. Rostral extremity ossa mandibulae (os dentale): (0) slightly curved; (1) curved; (2) strongly curved.

74. Width of the caudal aperture of the mandible: (0) short (about $30 \%$ of the total length of the mandible); (1) large (about $50 \%$ of the total length of the mandible).

75. Pars symphysialis mandible: (0) long (about $50 \%$ of the total length of the mandible); (1) short (about $40 \%$ of the total length of the mandible); (2) shortest (about $30 \%$ of the total length of the mandible).

76. Caudoventral region of the pars symphysialis mandibulae: (0) long and large; (1) short.

77. Fenestra caudalis mandibulae: (0) small aperture or absent; (1) narrow; (2) large and long.

78. Fossa aditus canalis neurovascularis mandibulae: (0) short and shallow; (1) long and shallow; (2) long and deep.

79. Proc. coronoideus 1 (rostral): (0) prominent; (1) vestigial.

80. Proc. medialis mandible: (0) reduced (about $5 \%$ of the total length of the mandible); (1) short (about $8 \%$ of the total length of the mandible); (2) long (about 10 a $13 \%$ of the total length of the mandible).

81. Cotyla medialis mandible: (0) shallow and large; (1) deep and narrow.

82. Cotyla lateralis and the cotyla caudalis mandible: (0) not fused to each other and deep; (1) fused to each other and deep; (2) fused to each other and shallow.

83. Proc. retroarticularis mandible: (0) large and rounded; (1) vestigial.

84. Tuberculum on the dorsal crista of the fossa caudalis mandible: (0) large; (1) narrow; (2) narrower (filiform); (3) vestigial.

85. Tuberculum intercotylaris mandible: (0) large; (1) narrow (crest in shape); (2) vestigial.

86. Fossa lateralis mandible: (0) deep; (1) shallow.

87. Fossa caudalis mandible: (0) large and deep; (1) narrow and deep; (2) narrower and shallow.

88. Ala postacetabularis ilii: (0) narrow; (1) large; (2) larger than 1 (embracing all lateral region of the pygostilum).

89. Os pubis: (0) long ( $70 \%$ of the total length of ala preacetabularis); (1) short ( $50 \%$ of the total length of ala preacetabularis).

90. Fonticuli lateralis of ala preacetabularis: (0) present; (1) absent.

91. Fonticuli lateralis of ala preacetabularis: (0) long and narrow; (1) long and large; (2) short.

92. Foramen ilioschiadicum: (0) $50 \%$ of the total length of the synsacrum; (1) $60 \%$ of the total length of the synsacrum; (2) $40 \%$ of the total length of the synsacrum.

93. Crista spinosa synsacri: (0) large and more prominent only in its rostral portion; (1) narrow and short; (2) narrow and short, but more prominent.

94. Ala preacetabularis: (0) narrow; (1) large. 
95. Crista iliaca dorsalateralis: (0) reduced and short; (1) long (extending, partially recovering, to foramen ilioischiadicum); (2) longer and dorsally larger than $\mathrm{n}$. 1.

96. Caudal tuberculum in the lateral surface of ala preacetabularis: (0) vestigial or absent; (1) prominent; (2) prominent and large; (3) prominent and large, but larger and in triangular shape.

97. Foramen orbituratum: (0) absent; (1) present.

98. Lamina pygostyli: (0) large; (1) large but even larger in its rostroventral portion.

99. Discus pygostyli: (0) narrow; (1) large.

100. Length of the proc. ventralis terminalis ischii: (0) $25 \%$ to $20 \%$ of the total length of the synsacrum; (1) $12 \%$ to $10 \%$ of the total length of the synsacrum.

101. Shape of the proc. ventralis terminalis ischii: (0) narrow and sharp; (1) large.

102. Proc. dorsalis terminalis ischii: (0) $10 \%$ of the total length of the synsacrum; (1) $5 \%$ of the total length of the synsacrum.

103. Proc. dorsalis terminalis ischii: (0) medially large and the apex is sharp; (1) narrow in it all extension and the apex is pointed; (2) narrow in it all extension and the apex is rounded; (3) narrow in it all extension and the apex is bifurcated; (4) medially large, but the apex is rounded.

104. Tuberculum on the dorsal surface sulcus articularis with os coracoideum: (0) prominent; (1) vestigial.

105. Bifurcation of the cranial apex of spina interna rostri: (0) absent; (1) present.

106. Length of spina interna rostri: (0) $10 \%$ of the total length of os sternum; (1) $15 \%$ of the total length of os sternum; (2) $20 \%$ of the total length of os sternum.

107. Shape of the spina interna rostri: (0) narrow (laterally flattened); (1) Large.

108. Crista dorsalis of the spina externa rostri: (0) present; (1) absent.

109. Proc. craniolateralis: ( 0 ) short ( $15 \%$ of the total length os sternum); (1) long ( $20 \%$ of the total length os sternum); (2) longer ( 25 to $30 \%$ of the total length os sternum).

110. Margo cranialis carinae: (0) perpendicular (straight); (1) semi-lunar in shape (curved).

111. Trabecula lateralis of the os sternum: (0) 50 to $60 \%$ of the total length os sternum; (1) $70 \%$ of the total length os sternum.

112. Trabecula intermedia of the os sternum: (0) $60 \%$ of the total length os sternum; (1) $50 \%$ of the total length os sternum.

113. Incisura lateralis or fenestra lateralis in relation to incisura medialis or fenestra medialis os sternum: (0) lateral longer than medial; (1) lateral with equal length to the medial.

114. Expansion carinae into trabecula medialis: (0) reduced or absent; (1) short and crest in shape; (2) long and dorsally large.

115. Dorsoventral depth carina sterni: (0) large; (1) narrow; (2) narrowest (reduced).

116. Proc. acrocoracoideus claviculae: (0) vestigial; (1) prominent.

117. Proc. interclavicularis: (0) vestigial; (1) rounded; (2) rounded, but larger and more prominent; (3) narrow and filiform.

118. Proc. acrocoracoideus os coracoideum: (0) vestigial; (1) prominent.

119. Proc. lateralis os coracoideum: (0) long, apex truncated (both tuberculum are reduced); (1) long but both tuberculum are prominent; (2) both tuberculum are prominent but longer than $\mathrm{n} .1$.

120. Length crista deltopectoralis os humerus: (0) short (20\% of the total length os humerus); (1) long ( $28 \%$ to $33 \%$ of the total length os humerus).

121. Width of the crista deltopectoralis os humerus: (0) reduced; (1) large; (2) idem 1, but larger and thick.

122. Olecranon os ulna: (0) long and thick: (1) short and thicker; (2) shorter than condition 1 (tubercular in shape).

123. Length of the os radius: (0) $25 \%$ to $33 \%$ longer than the length os humerus; (1) $10 \%$ longer than the length os humerus.

124. Tuberculum ligamentum collateralis ventralis: (0) vestigial; (1) prominent.

125. Papillae remigiales ventralis et caudalis: (0) prominent; (1) vestigial.

126. Tuberculum on the dorsal surface os metacarpale: (0) vestigial; (1) prominent; (2) more prominent.

127. Tuberculum of the caudal surface of the phalanx proximalis digiti majoris: (0) present; (1) absent.

128. Sulcus patellaris: (0) shallow; (1) deep.

129. Crista trochanteris: (0) vestigial; (1) prominent and large.

130. Sulcus intercnemialis: (0) large and deep; (1) narrow and shallow.

131. Total length os tibiotarsus: (0) $40 \%$ longer than the total length of the os femoris; (1) $50 \%$ longer than the total length of the os femoris; (2) $60 \%$ longer than the total length of the os femoris.

132. Facies gastrocnemialis os tibiotarsus: (0) narrow and shallow; (1) large and deep.

133. Total length os tarsometatarsus: (0) $75 \%$ the total length os femoris; (1) $90 \%$ the total length os femoris; (2) longer than the total length os femoris.

134. Rostral apex of the rhamphotheca: (0) slightly curved or not curved; (1) ventrally curved; (2) ventrally and strongly curved; (3) idem 2, but more curved (hooked in shape) and longer.

135. Relative size $4^{\text {th }}$ and $2^{\text {th }}$ toes (ossa digitorum pedis): (0) $4^{\text {th }}$ longer than $2^{\text {th }} ;(1) 4^{\text {th }}$ equal to $2^{\text {th }}$. 


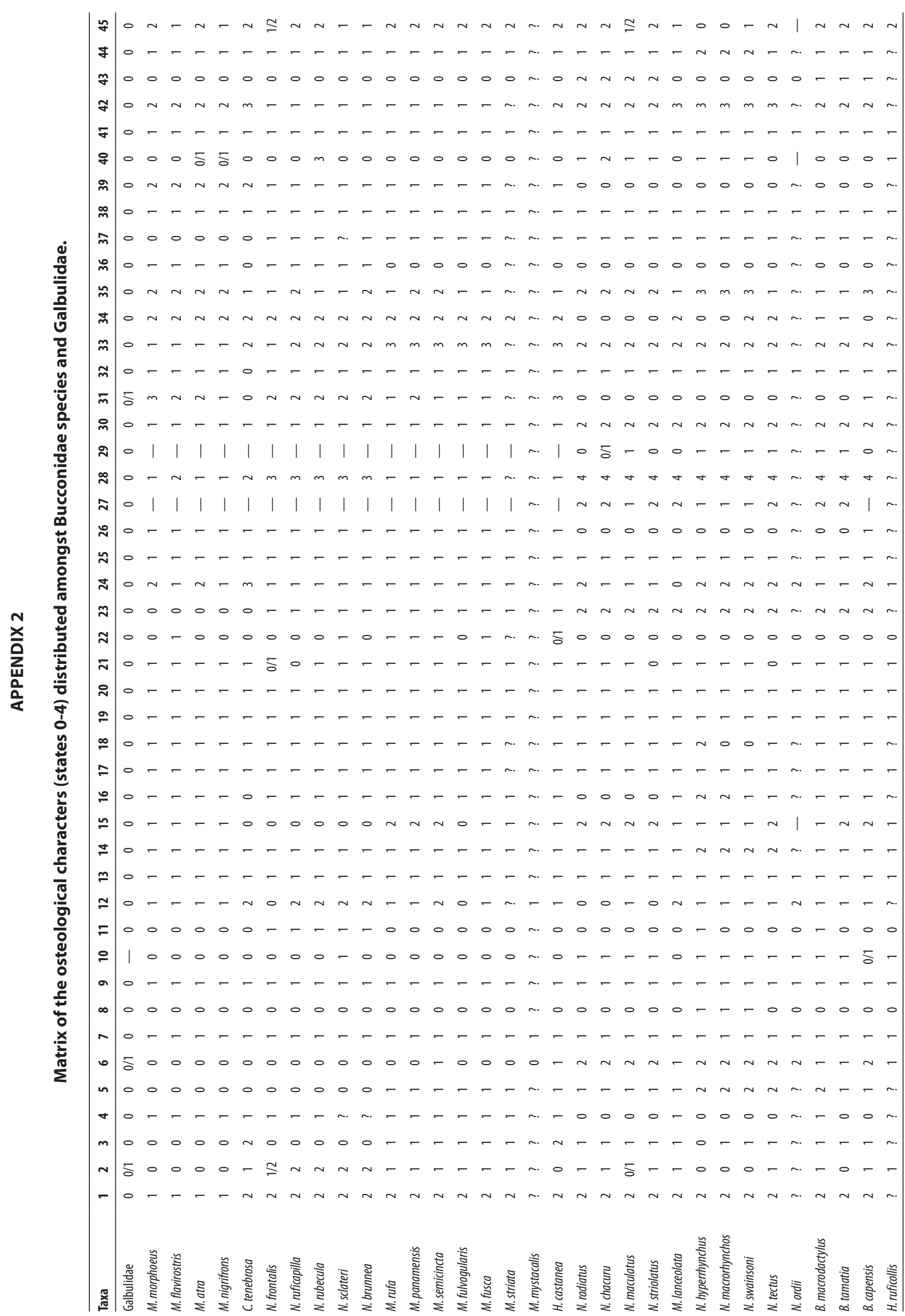




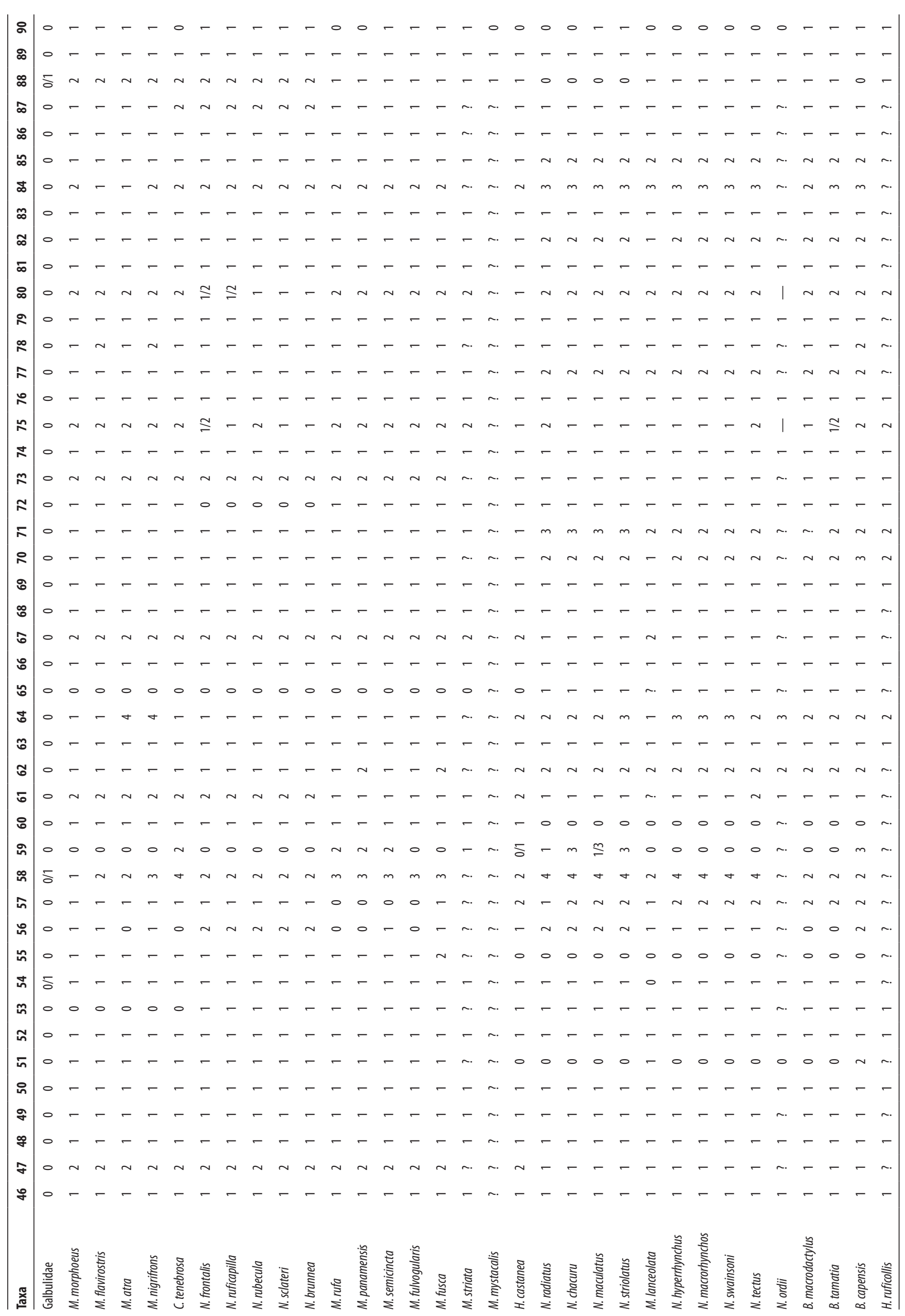




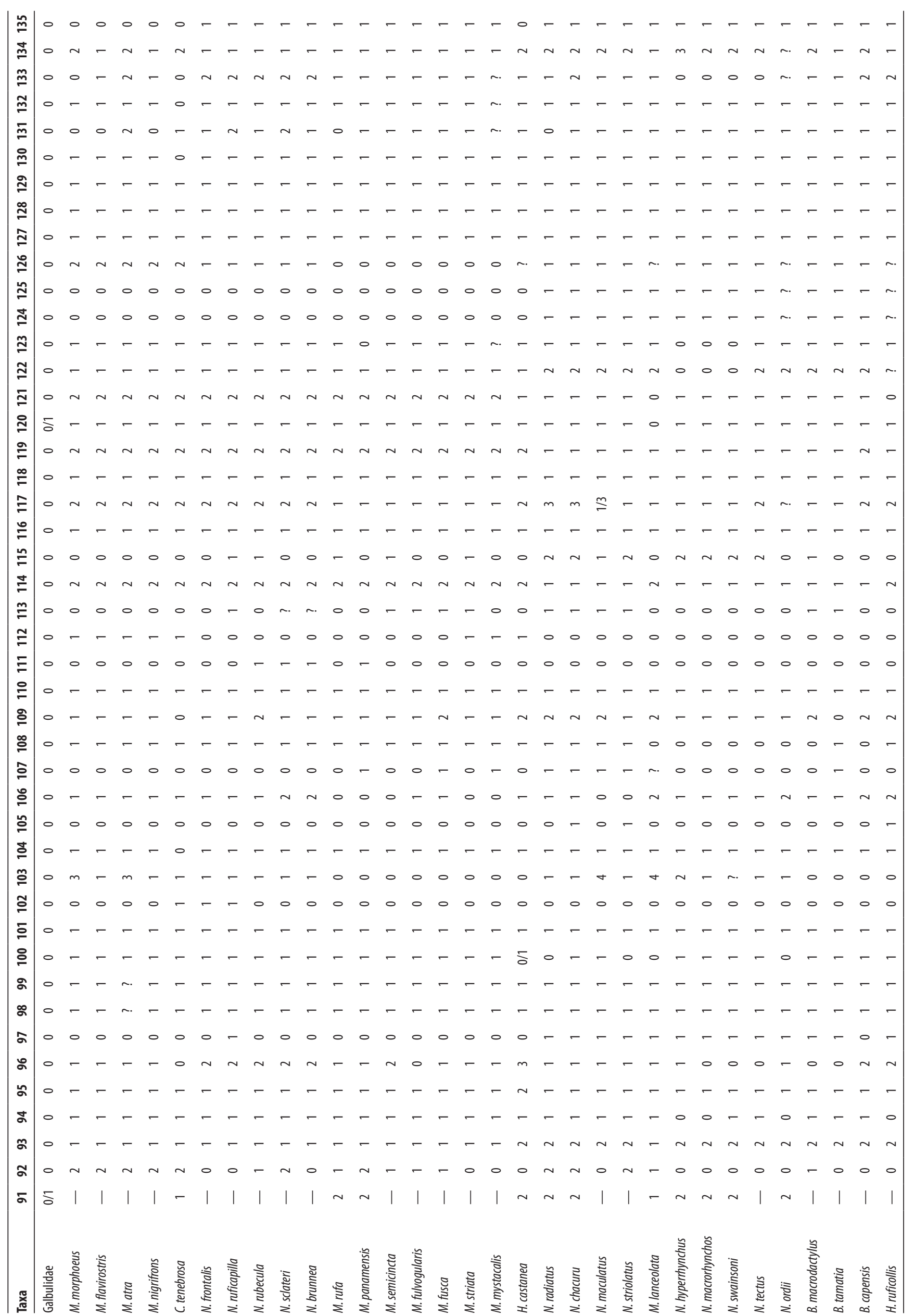




\section{APPENDIX 3}

\section{List of synapomorphies among species within the genera of Bucconidae. Consistency index (ci) and series of transformation for each character in parenthesis, respectively.}

Notharchus species: branch 9: $(1,0 \Rightarrow 1) ; 122(0.667,2 \Rightarrow 0) ; 123(0.333,1 \Rightarrow 0)$ and branch 10: $16(0.667,1 \Rightarrow 2) ; 34(0.5,2 \Rightarrow 0)$. Branch 12: $5(0.667,2 \Rightarrow 1) ; 15(0.286,1 \Rightarrow 2) ; 107(0.250,0 \Rightarrow 1) ; 108(0.25,0 \Rightarrow 1)$.

Nystalus species: branch 13: $6(0.4,1 \Rightarrow 2) ; 29(0.333,1 \Rightarrow 0) ; 34(0.5,1 \Rightarrow 0) ; 35(.333,1 \Rightarrow 2) ; 40(0.6,0 \Rightarrow 1) ; 56(0.286,0 \Rightarrow 2) ; 59(0.6,0 \Rightarrow 3)$; $88(0.5,1 \Rightarrow 0) ; 96(0.3,0 \Rightarrow 1) ; 106(0.25,1 \Rightarrow 0)$. Branch 14: $16(0.667,1 \Rightarrow 0) ; 43(1,1 \Rightarrow 2) ; 58(0.429,2 \Rightarrow 4) ; 71(1,2 \Rightarrow 3) ; 103(0.5,0 \Rightarrow 1) ;$ $115(0.222,0 \Rightarrow 1)$. Branch 15: $12(0.222,1 \Rightarrow 0) ; 92(0.182,0 \Rightarrow 2) ; 100(0.200,1 \Rightarrow 0) ; 105(0.333,0 \Rightarrow 1) ; 115(0.222,1 \Rightarrow 2)$. Branch 16: $90(0.2,1 \Rightarrow 0)$; $106(0.250,0 \Rightarrow 1) ; 117(0.5,1 \Rightarrow 3)$.

Malacoptila species: Branch 19: $35(0.333,1 \Rightarrow 2) ; 59(0.6,0 \Rightarrow 1) ; 106(0.25,1 \Rightarrow 0) ; 115(0.222,0 \Rightarrow 1)$. Branch 20: $15(0.286,1 \Rightarrow 2) ; 59(0.6,1 \Rightarrow 2)$. Branch 21: $56(0.286,1 \Rightarrow 0) ; 90(0.2,1 \Rightarrow 0) ; 113(0.2,1 \Rightarrow 0)$. Branch 22: $31(0.375,1 \Rightarrow 2) ; 62(0.5,1 \Rightarrow 2) ; 92(0.182,1 \Rightarrow 0) ; 107(0.25,0 \Rightarrow 1)$; $115(0.222,1 \Rightarrow 0) ; 123(0.333,1 \Rightarrow 0)$.

Nonnula species: Branch 24: $21(0.25,1 \Rightarrow 0) ; 102(0.5,0 \Rightarrow 1) ; 111(0.333,1 \Rightarrow 0)$. Branch 25:45 $(0.333,2 \Rightarrow 1) ; 106(0.25,1 \Rightarrow 2)$.

Monasa species: Branch 27: $24(0.429,1 \Rightarrow 2) ; 103(0.5,1 \Rightarrow 3) ; 133(0.286,1 \Rightarrow 0) ; 134(0.375,1 \Rightarrow 2)$. Branch 28: $45(0.333,2 \Rightarrow 1) ; 78(0.667,1 \Rightarrow 2)$. 